\title{
New Late Miocene Alilepus (Lagomorpha, Mammalia) from Eastern Europe - a new light on the evolution of the earliest Old World Leporinae
}

\author{
STANISLAV ČERMÁK, CHIARA ANGELONE \& MAXIM V. SINITSA
}

\begin{abstract}
The leporid material from eight Late Miocene (MN11-13) localities of Ukraine and Moldova is described. The analysis is supported by a direct revision of type materials of A. laskarewi, A. hungaricus and A. ucrainicus. Lectotypes of A. annectens (type species of Alilepus), A. laskarewi and A. hungaricus are designated here. The new material from Egorovka 2 (MN12) allowed a detailed morphometric re-description and emended diagnosis of A. laskarewi, one of the least understood species of the Old World Alilepus. One of the peculiarities of A. laskarewi is the very high incidence of mesofossettid in p3. The oldest leporids of the study area are verified for the MN11 localities Palievo, UA and Keinar, $\mathrm{MD}$, but the taxonomy for these very scanty records remains unclear. In the light of the new material presented here, (i) a synoptic survey and discussion on the presence of $\mathrm{p} 3$ mesofossettid and (ii) hypotheses on a possible evolution and dispersal among the Old and New World Leporinae are provided. $\bullet$ Key words: Alilepus, taxonomy, phylogeny, Late Miocene, Pliocene, Eastern Europe.
\end{abstract}

ČERMÁK, S., ANGElone, C. \& SinitSA, M.V. 2015. New Late Miocene Alilepus (Lagomorpha, Mammalia) from Eastern Europe - a new light on the evolution of the earliest Old World Leporinae. Bulletin of Geosciences 90(2), 431-451 (6 figures, 2 tables). Czech Geological Survey, Prague. ISSN 1214-1119. Manuscript received June 10, 2014; accepted in revised form November 6, 2014; published online March 9, 2015; issued March 23, 2015.

Stanislav Čermák, Institute of Geology, Academy of Sciences of the Czech Republic, v.v.i., Rozvojová 269, 16500 Prague 6, Czech Republic; cermaks@gli.cas.cz - Chiara Angelone, Grup de recerca de Faunes del Neogen $i$ Quaternari, Institut Català de Paleontologia Miquel Crusafont, Universitat Autònoma de Barcelona, Edifici ICP, Campus de la UAB s/n, 08193 Cerdanyola del Vallès, Barcelona, Spain; chiara.angelone@icp.cat • Maxim V. Sinitsa, Paleontological Museum, National Museum of Natural History, National Academy of Sciences of Ukraine, Bohdan Khmelnitsky str.15,01-601 Kiev, Ukraine; sinitsamax@gmail.com

The genus Alilepus represents one of the most ancient forms of the Leporinae clade. Its origin can be traced back to the late Middle Miocene of North America (Voorhies \& Timperley 1997). During the Late Miocene Alilepus arrived in Eurasia through Beringia. The widespread of leporids in Eurasia, the first of which most probably was Alilepus, marked a "revolution" in the ecosystems, determining the definitive decline of the ochotonids that since the Early Miocene dominated the Old World.

A century ago, Khomenko (1914) erected from the Moldovan locality Tarakliya (MN12) Lepus laskarewi, the species representing now the oldest available name among the Old World Alilepus. Since then neither the type nor other relevant material has been studied in detail to revise this poorly known species. The genus Alilepus was erected later by Dice (1931), as a new replacement name of Allolagus Dice 1929, based on the type species Lepus annectens Schlosser, 1924. Dice (1929, p. 342) diagnosed the new genus based on its p3 formed by "two columns connected in the centre of the tooth by a bridge of dentine" [a direct quote from Schlosser (1924, p. 46)].

In spite of its importance for palaeobiogeography, biochronology and palaeoecology, Alilepus lacks a thorough revision in Eurasia. This paper is aimed to take stock of the situation of the genus Alilepus in Europe, in order to:

1) provide a taxonomic/nomenclatural basis for subsequent systematic considerations of European Alilepus by a revision of type materials of all available names of European species of Alilepus, with special respect to direct analysis and revision of the very poorly known type materials of A. laskarewi, A. hungaricus and A. ucrainicus;

2) provide a detailed morphometric re-description of A. laskarewi and formulate its emended diagnosis based on the new Alilepus material from eastern European localities;

3) provide in the Holoarctic context (a) a synoptic survey and discussion about the presence of the mesofossettid in the p3s of leporids, and (b) hypothesize a possible evolution and dispersal of the earliest Leporinae. 


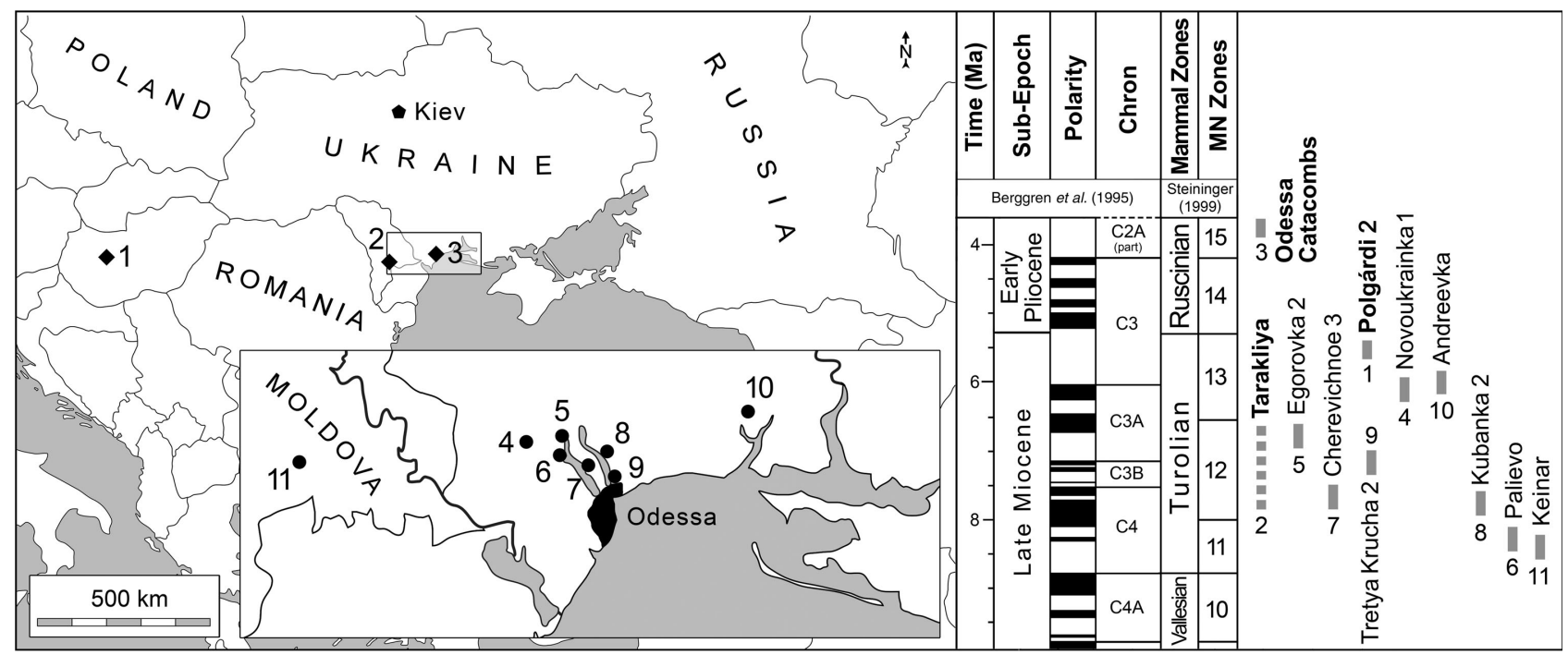

Figure 1. Geographical localization and age estimation of the fossil sites under study, including type localities Polgárdi 2, Tarakliya and Odessa Catacombs.

\section{Geographical and geological setting of the new Alilepus-bearing fossil localities}

The Alilepus material analyzed in this paper comes from eight Late Miocene (MN11-13) localities of Ukraine and Moldova. Their locations and chronologic relationships are illustrated in Fig. 1.

Andreevka [Андреевка]. - Thin lens of alluvial gravels embedded in a large sequence of Late Meotian siltstone and clay covered by a typical Upper Pontian shell limestone (Berezanski district, Nikolaev region, Ukraine). Association with Pseudocricetus kormosi, Apodemus dominans, Apodemus gorafensis and Pliospalax (Nannospalax) compositodontus suggests a Late Turolian (MN13) age.

Novoukrainka 1 [Новоукраинка 1]. - The locality (Razdelnyanski district, Odessa region, Ukraine) consists of several lenses of gravels and sandy gravels with a moderately rich fossil bed. The fossiliferous layer occurs within a large sequence of the Upper Chersonian, Meotian and Pontian siltstones, clays, sands and limestones. The faunal composition is identical with Andreevka, but Pseudocricetus shows an earlier evolutionary stage than in Andreevka.

Egorovka 2 [Егоровка 2]. - The locality is situated on the right riverbank of the Svinaya River near the village of Egorovka (Razdelnyanski district, Odessa region, Ukraine). The bones of small mammals were scattered in a thick lens of clayey gravels and siltstones. A very rich mammal assemblage is characterized by the predominance of Pseudocricetus orienteuropaeus, Apodemus schaubi, A. cf. dominans and $A$. aff. lugdunensis. Other taxa such as Myomimus maritsensis, Muscardinus cf. pliocaenicus, Vasseuromys aff. pannonicus, "Sciurotamias" aff. gromovi, Pliopetaurista sp., Euroxenomys minutum, Chalicomys sp., anomalomyids, bats and lipotyphla form a minor part of this assemblage. The locality is noteworthy for the absence of ochotonids. The age of this small mammal community is correlated with the Middle Turolian (MN12), a slightly younger than Cherevichnoe 3, Tretya Krucha 2 and Kubanka 2.

Tretya Krucha 2 [Третья Круча 2]. - An abandoned artificial outcrop with a thick layer of Middle Meotian gravels exposed on the riverbank of Kuyalnitski Liman (Kominternovski district, Odessa region, Ukraine). The moderately rich fossil bed contains a typical Middle Turolian (MN12) small mammal assemblage with Pseudocricetus orienteuropaeus, A. lugdunensis and Apodemus cf. schaubi.

Cherevichnoе 3 [Черевычное 3]. - The locality (Belyaevski district, Odessa region, Ukraine) is located in Lower Meotian gravels rich in small vertebrate fossils. Detailed information on the locality is given in Topachevski et al. (2000). Based on the predominance of Pseudocricetus antiquus, Apodemus barbarae, A. lugdunensis, Vasseuromys cf. pannonicus and the peculiar hamster Stylocricetus, this assemblage is believed to Middle Turolian in age (MN12).

Kubanka 2 [Кубанка 2]. - The locality is located in gravelly level(s) of a small abandoned sand quarry close to the Kubanka village (Kominternovski district, Odessa region, Ukraine). The small mammal fauna of Kubanka 2 is poorly investigated and understood, so a detailed biostratigraphic correlation of the locality is not yet possible. The presence of Pseudocricetus aff. orienteuropaeus, Apodemus barbarae, A. lugdunensis, Vasseuromys pannonicus, Pliopetau- 



Figure 2. Dental terminology and morphology of leporid p3 and P2. • A - terminology and position of enamel structures in p3 and P2 (after Palacios \& López Martínez 1980 supplemented with terminology by White 1991 - in parentheses). • B - categorization of basic enamel p3 patterns based on the combination of (1) presence/absence of anteroroflexid (morphotypes A0-A1), (2) development of morphostructures between trigonid and talonid (morphotypes PR0-PR4) and (3) development of paraflexid (morphotypes Pa0-Pa3). $\bullet \mathrm{C}$ - detailed morphological characterization of anterior and buccal enamel structures of p3 and P2 (after the scheme of morphological classes originally used for Hypolagus in Čermák [2009, fig. 5; based on Fladerer 1987 and/or Fladerer \& Reiner 1996]).

rista cf. bressana and Eozapus intermedius suggests a Middle Turolian (MN12) age.

Palievo [Палиево]. - The locality outcrops in the steep riverbank of the Khadzhibeiski Liman (Razdelnyanski district, Odessa region, Ukraine). Most fossil remains were recovered from a thin layer of gravel covered by Lower Chersonian oolithic limestone and greenish clay. The small mammal assemblage of Apodemus barbarae, A. lugdunensis, Kowalskia progressa, Stylocricetus sp., Lophocricetus complicidens, Vasseuromys aff. pannonicus, Muscardinus sp., Ochotona spp., Prolagus sp., Schizogalerix cf. moedlingensis, Archaeodesmana aff. vinea and "Paenelimnoecus" repenningi suggests an Early Turolian age (MN11).

Keinar [Cainari]. - The locality is situated on the right side of the Botna River, near the town of Keinar (Caușeni region, Moldova). Several thick (up to $1.5 \mathrm{~m}$ ) layers and lenses of alluvial gravels are embedded in a large sequence of Late Sarmatian freshwater and marine deposits with abundant shells of mollusks (Mactra caspia, M. bulgarica, Unio, Planorbis, Helix). Lungu \& Rzebik-Kowalska (2011) date the locality to the late Vallesian (MN10). How- ever, the presence of Apodemus lugdunensis and species of Kowalskia similar to K. skofleki from Eichkogel (not to K. falhbuschi from Kohfidisch [M. Sinitsa, pers. obs. 2013]), excludes a Late Vallesian age. Thus the small mammalian fauna from Keinar is correlated here with the Early Turolian (MN11).

A list of the localities with brief characteristics, accompanied by major literature sources, is summarized in Table 1.

\section{Material and methods}

The type material of European Alilepus is in collections of the MFGI (A. hungaricus), MSN-UF (A. meini), PMONU (A. laskarewi), UM (A. turolensis) and ZIN RAS (A. ucrainicus). The newly described leporid material from the Late Miocene localities of Ukraine (Andreevka, Cherevichnoe 3, Egorovka 2, Novoukrainka 1, Kubanka 2, Palievo, Tretya Krucha 2) and Moldova (Keinar) is deposited in the collections of the NMNHU and FGTU, respectively. Comparative and/or additional material from Moldovan localities Chimishliya (MN12) and Gradishte (MN12) is deposited in the collections of the MENH and FGTU. 
Table 1. List of Late Miocene localities with Alilepus studied in this paper. Explanatory notes: - A - name of the locality (country abbreviation). - B - biostratigraphic correlation (MN zones sensu Steininger 1999). • C - biostratigraphic significance of the mammalian record from the locality: 1 - abundant community samples in a continuous sequences and/or a very abundant point record (enabling a quantitative treatment), 2 - a sequence in which at least some samples allow a quantitative approach, or a representative point sample, $3-\mathrm{a}$ less representative point record. $\bullet \mathrm{D}-$ state of preservation of fossil material: a - well preserved (i.e., available fragments of skulls, teeth and parts of postcranial skeletons are abundant), b - moderately well preserved (i.e., fragments of skulls are rare, isolated teeth are predominant), c - poorly preserved (i.e., isolated teeth are available almost exclusively, moreover mostly corroded or damaged). $\bullet$ E - major references to the localities.

\begin{tabular}{lcccl}
\hline A & B & C & D & E \\
\hline Andreevka (UA) & MN13 & 2 & a & Topachevski \& Skorik (1992), Nesin \& Nadachovski (2001) \\
Novoukrainka 1 (UA) & MN13 & $2 / 3$ & b/c & Korotkevich (1988), Topachevski \& Skorik (1992), Nesin \& Nadachovski (2001) \\
Egorovka 2 (UA) & MN12 & 1 & a & Sinitsa (2008, 2009a) \\
Tretya Krucha 2 (UA) & MN12 & 3 & a & Sinitsa (2005) \\
Cherevichnoe 3 (UA) & MN12 & 1 & b & Topachevski et al. (2000), Nesin \& Nadachovski (2001), Nesin (2013) \\
Kubanka 2 (UA) & MN12 & 2 & b & Sinitsa (2011) \\
Palievo (UA) & MN11 & 1 & b & Sinitsa (2009b, 2012) \\
Keinar (MD) & MN11 & 2 & b & Lungu (1980), Lungu \& Rzebik-Kowalska (2011) \\
\hline
\end{tabular}

Dental terminology and metrics used to describe these structures follow Sych (1965) and Palacios \& López Martínez (1980). The position of enamel structures in p3 and P2, supplemented with terminology by White (1991), is shown in Fig. 2A. The general enamel p3 pattern of Leporidae is categorized here based on the combination of presence/absence or degree of development of (1) anteroroflexid (morphotypes A0-A1), (2) morphostructures between the trigonid and talonid (morphotypes PR0-PR4) and (3) paraflexid (morphotypes $\mathrm{Pa} 0-\mathrm{Pa} 2$ ). The classification scheme is summarized in Fig. 2B. Sequences (A0-A1, PR0-PR4, Pa0-Pa3) of structures in the scheme do not represent stages of morphoclines. More detailed morphological characterization of anterior and buccal enamel structures of p3 and P2 (Fig. 2C) follows the scheme of morphological classes originally used for Hypolagus in Čermák (2009, fig. 5; based on Fladerer 1987 and/or Fladerer \& Reiner 1996). Here we reserve the formal term "Leporinae", or informally "leporines" for a leporid group including Alilepus and their presumed descendants. For the group with taxa distantly related to that radiation, we use term "Leporidae", or informally "leporids".

Drawings and measurements were made with a camera lucida and ocular micrometer on a binocular microscope. Outline maps used in Figure 1 were taken from http://d-maps.com/. All measured data are given in millimeters. Biostratigraphic terminology follows Fejfar \& Heinrich (1983), Semenenko (1987), Nesin (1996, 2004) and Fejfar et al. (1998). The North American fossil record is correlated also with the NALMA system (North American land mammal ages). All nomenclatural acts presented here conform to the mandatory provisions of the International Code of Zoological Nomenclature (ICZN 1999).

Abbreviations. - EL - enamel lake; FGTU - Faculty of Geography of Tiraspol State University, Department of
General Geography, Kishinev, Moldova; GLI - Institute of Geology AS CR, v.v.i., Prague, Czech Republic; L - length; Ltrig - trigonid length; Ltal - talonid length; M - mean; MENH - National Museum of Ethnography and Natural History, Kishinev, Moldova; MFGI - Magyar Földtani és Geofizikai Intézet (Hungarian Institute of Geology and Geophysics), Budapest, Hungary; MSN-UF - "Museo di Storia Naturale" (Geology and Palaeontology Section), University of Florence; N - number of specimens; NMNHU - National Museum of Natural History, V. Topachevsky Palaeontological Museum, Kiev, Ukraine; PMONU - Odessa I.I. Mechnikov National University, Palaeontological Museum, Odessa, Ukraine; OR - observed range; $\mathrm{Wg}$ - width of internal fault in $\mathrm{I}$; W Wrig - trigonid width; Wtal - talonid width; UM2 - University of Montpellier 2; ZIN RAS - Zoological Institute, Russian Academy of Sciences, Saint Petersburg, Russia. Country abbreviations follow ISO 3166-1 alpha-2 codes. P/p (premolars) and $\mathrm{M} / \mathrm{m}$ (molars) refer to upper and lower cheek-teeth, respectively.

\section{Type material of European species of Alilepus}

Before our systematic revision of studied taxonomic taxa from localities of Ukraine, we must clarify uncertainties in type materials of European Alilepus species. In the Miocene-Pliocene of Europe five available (fulfilling the conditions of Article 13.1.1 of ICZN 1999) species names of Alilepus have been described. With the exception of the recently erected A. turolensis and A. meini, European Alilepus (i.e., A. laskarewi, A. hungaricus and A. ucrainicus) are described insufficiently, and their type material urges a revision. To further complicate the situation, the fossil record of European species of Alilepus is scanty and fragmentary, 
represented mostly by dentition only. Moreover some species (A. hungaricus, A. meini and A. ukrainicus) are well proven only from their type localities by the original type series. Thus, an evaluation of the taxonomic validity of all European species, based on such limited material, cannot be resolved sufficiently, and is beyond the scope of this paper. The aim here is to review all nomenclaturally important data, including - if necessary - a proper name-bearing type fixation and, based on direct analysis of poorly known type materials of A. laskarewi, A. hungaricus and A. ucrainicus, to provide emended descriptions. For the sake of completeness we report here also details, with principal literature references, concerning the type materials of $A$. $t u$ rolensis and A. meini.

\section{Alilepus laskarewi (Khomenko, 1914) \\ Figure 3A1-A4}

Type series. - The type material was collected by I.P. Khomenko from Tarakliya [Taraclia, Тараклия] in 1912. The exact location of the fossil site (situated in the northwestern part of Tarakliya village) is unknown (Delinschi pers. comm. 2013). The nominal taxon Lepus laskarewi was established by Khomenko (1914) based on the syntype (Article 73.2 of ICZN 1999) consisting of a right mandible with p3-m3 (Khomenko 1914, p. 12, pl. I, figs 19, 20) and two forelimb phalanges (Khomenko 1914, p. 12, pl. I, figs 9, 10). No single name-bearing type specimen was designated, neither originally (holotype [Article 73.1]) nor subsequently (lectotype [Article 74]). At present in the collections of the PMONU only a right mandible can undoubtedly be identified with the original material described by Khomenko (1914).

Name-bearing type. - Lectotype (designated in this paper)right mandible with p3-m3 (No. 3403, Fig. 3A1-A4); collections of the PMONU.

Type locality and age. - Tarakliya (Keushen region), Moldova; Middle Turolian, MN12.

Emended description of the type material. - Mandible: Mandibular body with p3-m3, damaged in its ventral part. Its size and the cylindrical crown of the teeth indicate that it is an adult individual.

p3: The damage in the ventral part of the jaw reveals the "radical" part of the tooth, and shows that the A0/PR1/Pa0 morphotype is maintained along the whole tooth crown. The simple, unilobated anteroconid (morphotype II) is relatively long (about $1 / 3$ of tooth length). The walls of the shallow protoflexid form a nearly right angle. The trigonid and talonid are connected by a thin isthmus, as the hypoflexid and mesoflexid are both quite deep. The medial part of the hypoflexid is of the "C/D" morphotype. The labial part of hypoconid is of the "c" morphotype.

Lower molariforms: In p4-m3 no reentrant is present at the antero-buccal corner of the trigonids; the anterior and antero-buccal walls of talonids are without infoldings or undulation.

Measurements. - Mandible: alveolar length of p3-m3 = 13.4; 3 : $\mathrm{L}=3.20, \mathrm{~W}=2.82 ; \mathrm{p} 4: \mathrm{L}=2.84$, Wtrig $=3.37$, $\mathrm{Wtal}=2.74 ; \mathrm{m} 1: \mathrm{L}=2.84, \mathrm{Wtrig}=3.32, \mathrm{Wtal}=2.58 ; \mathrm{m} 2$ : $\mathrm{L}=2.89$, Wtrig $=3.45$, Wtal $=2.63 ; \mathrm{m} 3: \mathrm{L}=2.21$, Wtrig $=$ 2.16, Wtal $=1.39$.

Lectotype designation. - In the sense of Articles 74.7 and Declaration 44, we hereby designate the right mandible with p3-m3 (No. 3403, Fig. 3A1-A4) as a lectotype (Article 74.7.1 and Declaration 44) of the nominal taxon of Lepus laskarewi Khomenko, 1914 described from the Middle Turolian (MN12) locality Tarakliya (Moldova).

Remarks. - The species name "laskarewi" represents the oldest available species name within the Old World Alilepus. The correct original spelling of the species name (Article 32.1 of ICZN 1999) is A. laskarewi; thus, subsequent spellings A. lascarevi, A. lascarewi, or A. laskarevi reported in the literature (e.g., Kormos 1934, Gureev 1964, Daxner \& Fejfar 1967, López Martínez 1976, Qiu \& Han 1986, Jin 2004, Lungu et al. 2007, Jin et al. 2010) must be regarded as incorrect (Article 33.3 of ICZN 1999).

\section{Alilepus hungaricus Kormos, 1934}

Figure 3B1-C

Type series. - The type material was collected by T. Kormos in 1910 (Kormos 1911). The nominal taxon Alilepus hungaricus was established by Kormos (1934) based on the syntype (Article 73.2 of ICZN 1999) consisting of a left mandible with $\mathrm{p} 3-\mathrm{m} 2$ and a right maxilla with P3-M1. No single name-bearing type specimen was designated, neither originally (holotype [Article 73.1]) nor subsequently (lectotype [Article 74]). In the collections of the MFGI, we found both the specimens under the catalogue number Ob. 5068.

Name-bearing type. - Lectotype (designated in this paper) left mandible with p3-m2 (Ob. 5068; Fig. 3B1-B5); collections of the MFGI.

Type locality and age. - Polgárdi 2, Hungary; Late Turolian, MN13.

Emended description of the type material. - Mandible: Lingually damaged mandibular body with p3-m2. The buccal surface of the body is fenestrated below p3-p4. The 
root end of the lower incisive alveolus extends below the anterior border of p3. Available teeth are not conical attesting that this is an adult individual.

p3: The A0/PR1/Pa0 morphotype is maintained along the whole tooth crown. The anteroconid (between morphotypes II and III) is relatively short (less than $1 / 3$ of tooth length) and markedly widened lingually. A very shallow, medially undulated protoflexid has walls forming an obtuse angle. The hypoflexid slightly indents the talonid and is crenulated in its distal side. The medial part of the hypoflexid is of the " $\mathrm{B}$ " morphotype. The mesoflexid end is bilobed and in radical view its distal side is undulated. The connection between the trigonid and talonid is relatively wide. The labial part of the hypoconid is of the " $c$ " morphotype. The enamel band is thin.

Lower molariforms: The trigonid is short (Ltri < Ltal) in p4-m1; a reentrant at the antero-buccal corner of the trigonids is absent. The trigonids appear massive, prominent and rounded in the labial side, especially in $\mathrm{p} 4-\mathrm{m} 1$. In $\mathrm{p} 4$ the posterior wall of the trigonid is medially undulated and has a central tip oriented posteriorly. In all molariforms the anterior wall of the talonids is undulated, but without deep infoldings, and the degree of undulation decreases from $\mathrm{p} 4$ to $\mathrm{m} 2$; a small antero-buccal reentrant is present.

Maxilla: In ventral view, the incisive foramen extends to the posterior margin of the alveolus of P2. The choanae reach the P4/M2. The palatine occupies about $40 \%$ of the length of the palatal bridge. The major palatine foramen is located next to the hypostria of P4. The masseteric spine is thin and long, and does not expand laterally.

Upper molariforms (P3-M1): The internal reentrant (= hypostria) extends approximately halfway across the tooth and is crenulated on both sides.

Measurements. - Mandible: height at $\mathrm{m} 2 / \mathrm{m} 3=12.53$; 3 : $\mathrm{L}=3.00, \mathrm{~W}=2.97$; $4: \mathrm{L}=2.72, \mathrm{Wtrig}=3.39, \mathrm{Wtal}=2.78$; $\mathrm{m} 1: \mathrm{L}=2.83$, Wtrig $=3.22$, Wtal $=2.50 ; \mathrm{m} 2: \mathrm{L}=2.72$, Wtrig $=3.06$, Wtal $=2.47$; maxilla: alveolar length of P2-M3 = 15.54, minimum length of hard palate $=7.25 ;$ P3: $\mathrm{L}=2.03$, Want $=3.31$, Wpost $=4.14 ; \mathrm{P} 4: \mathrm{L}=2.11$, Want $=$ $3.83, \mathrm{Wpost}=3.89 ; \mathrm{M} 1: \mathrm{L}=2.08, \mathrm{Want}=3.47, \mathrm{Wpost}=$ 3.61 .

Lectotype designation. - In the sense of Articles 74.7 and Declaration 44, we hereby designate the right mandible with p3-m2 (Ob. 5068, Fig. 3B1-B5) as a lectotype (Article 74.7.1 and Declaration 44) of the nominal taxon of Alilepus hungaricus Kormos, 1934, described from the Late Turolian (MN13) locality Polgárdi 2 (Hungary). In the context of the fixation of the left mandible (Ob. 5068) as a lectotype, the right maxilla (V.2013.49.1 - a new exclusive catalogue number) becomes a paralectotype (Article 74.1.3 of ICZN 1999).
Remarks. - In past years, A. hungaricus has been included in a different, monospecific genus: Veterilepus (V. hungaricus in Radulesco \& Samson 1967). This was based on the crenulation of the distal part of the posterior flexids of $\mathrm{p} 3$, as those authors noticed that this condition was "different from all Alilepus s.s., in which the enamel of this tooth is smooth" (ib., p. 554). Veterilepus was considered to be the ancestor of a lineage independent from that of A. annectens.

Our opinion, based on our observation of Hungarian material and in the light of the present state of the art of fossil leporid taxonomy, is that the material from Polgárdi 2 is not distinctive enough to be considered a genus different from Alilepus. A comparable and even higher degree of enamel crenulation has been reported in other species of Alilepus (e.g., Alilepus meini from Europe and A. lii from Asia) and does not constitute a generic level character. Thus, we consider the leporid from Polgárdi 2 as pertaining to the genus Alilepus.

\section{Alilepus ucrainicus Gureev, 1964}

Figure 3D1-H3

Type series. - The type series (Articles 72.1.1 and 72.4.1) consists of two (glued together) maxillas (4998; Fig. 3H1) and four mandible fragments (4976-4979; Fig. 3D1-G2). The nominal taxon Alilepus ucrainicus was fixed in $\mathrm{Gu}-$ reev (1964, p. 124) by a holotype (sensu Article 73.1.1 of ICZN 1999).

Name-bearing type. - Holotype - right mandible with p3-p4, m2 (No. 4976, No. C. 61528; Fig. 3D1, D2); collections of the ZIN RAS.

Type locality and age. - Odessa Catacombs, Ukraine; Late Ruscinian, MN15b.

Emended description of the type material. - Mandible: The four mandibles belong probably to two individuals: specimens 4976 (holotype) and 4977 to an adult, and specimens 4978 and 4979 to a subadult (as their teeth appear to be conical in lateral view, Fig. 3F1, G2). The diastema is relatively long, about $20 \%$ longer than the alveolar length of p3-m3, and in buccal view it appears concave along its entire length. The dorsal surface of the mandibular body is convex, but without the distinctive swelling below p3-p4. The buccal surface of the mandibular body is richly fenestrated. The large antero-bucally directed mental foramen is on the dorso-buccal side about $2.7 \mathrm{~mm}(\mathrm{~N}=2)$ beneath the $\mathrm{p} 3$.

p3: The A0/PR1/Pa0 morphotype is present in all available teeth, and in specimens 4978 and 4979 this morphotype is verifiable also in the "radical" end. The 


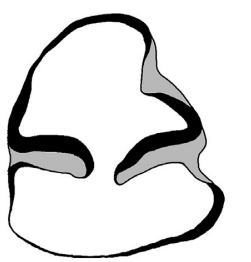

A1

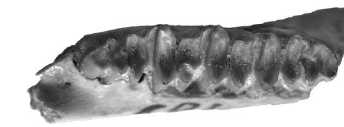

A2
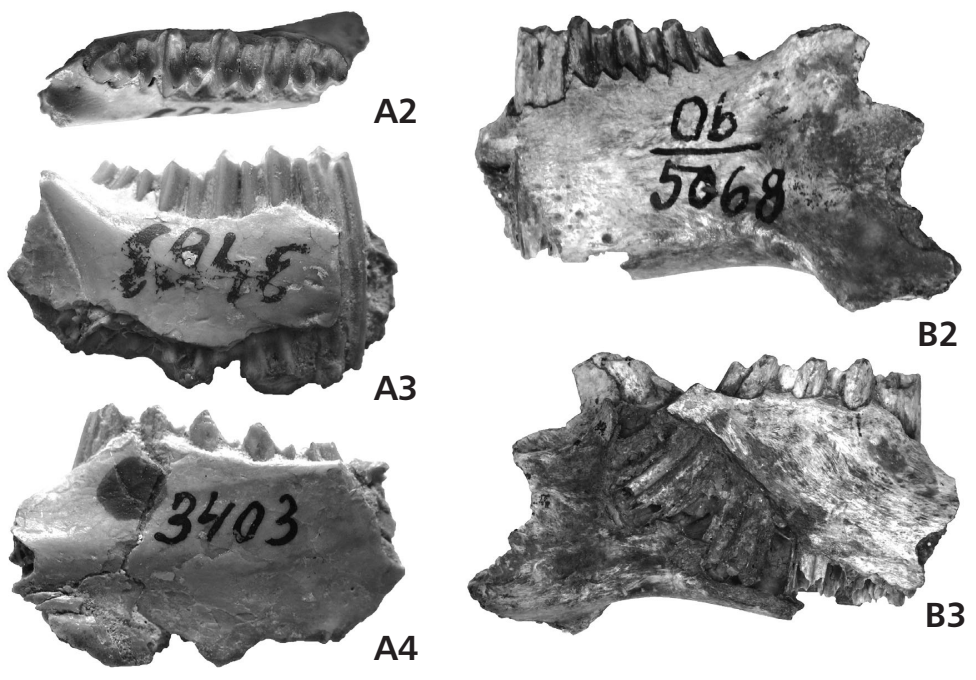

B2



B1

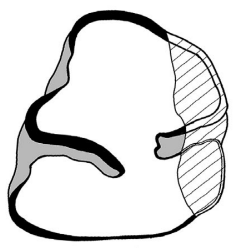

B4
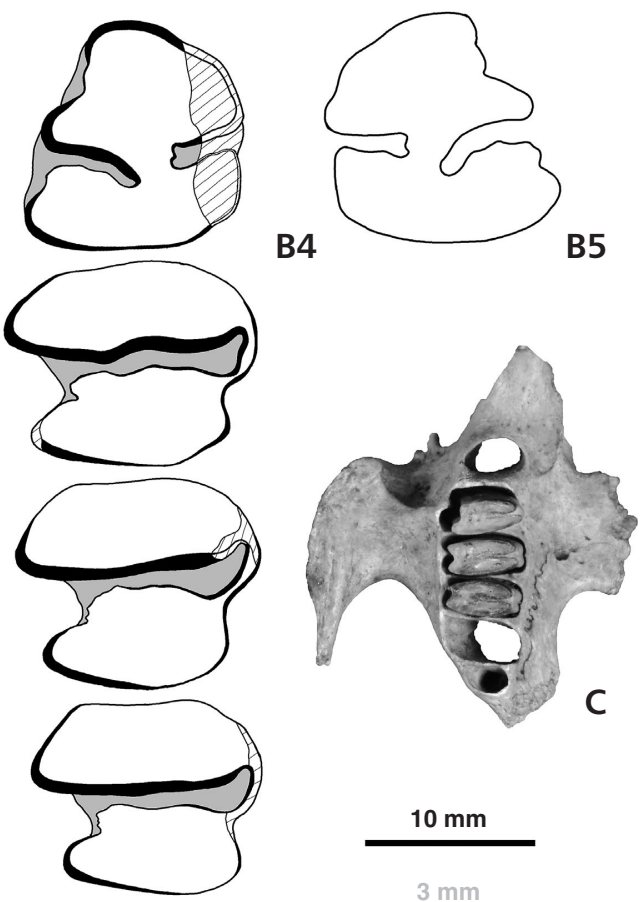

C
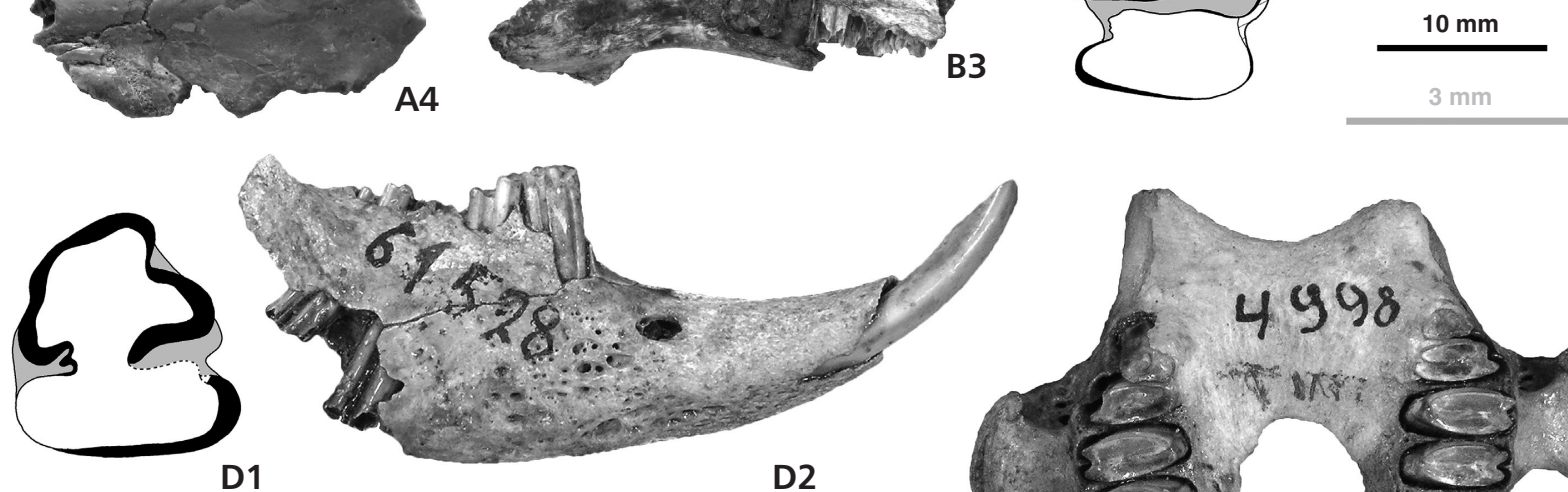

D1

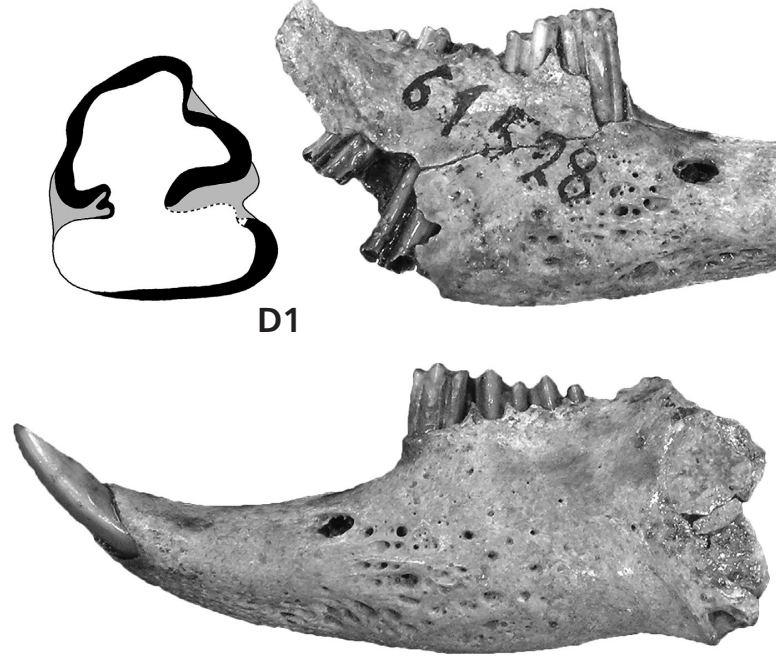

E1

D2

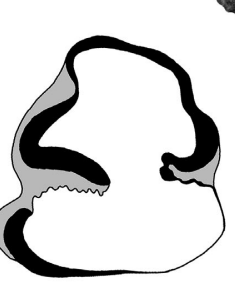

E2


$\mathrm{H} 2$

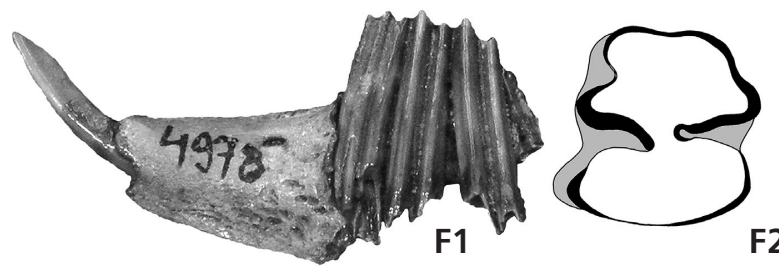

F2

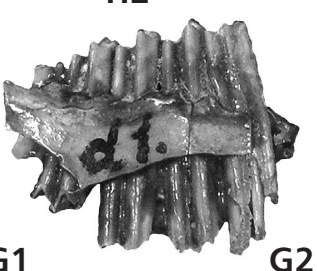

G2

Figure 3. Type materials of Central and Eastern European Alilepus species. A A1-A4-Alilepus laskarewi (Khomenko, 1914), lectotype (designated in this paper), right mandible with p3-m3 (No. 3403); A1 - p3 (occlusal view); A2-A4 - mandible; A2 - dorsal view; A3 - buccal view; A4 - lingual view. -B1-C - Alilepus hungaricus Kormos, 1934; B1-B5 - lectotype (designated in this paper), left mandible with p3-m2 (Ob. 5068); B1-B3 - mandible; B1 - dorsal view; B2 - buccal view; B3 - lingual view; B4-B5 - teeth; B4 - p3-m2, occlusal view; B5 - p3, radical view; C - right maxilla (V2013.49.1.) with P3-M1 ventral view. •D1-H3 - Alilepus ucrainicus Gureev, 1964; D1-G2 - mandibles (buccal views) and their p3s (occlusal views); D1, D2 - holotype, right mandible with p3-p4, m2 (No. 4976 [No. C. 61528]); E1, E2 - left mandible with p3-m1 (No. 4977); F1, F2 - left mandible with p3-m1 (No. 4978); G1, G2 - right mandible with p3-m3 (No. 4979); H1-H3 - two isolated upper jaws (No. 4998; glued together) with P2-M3 (left) and P2-M2 (right); H1 - upper jaw, ventral view; H2 - right P2, occlusal view; H3 - left P2, occlusal view. Scale bars: grey $(3 \mathrm{~mm})$ for teeth, black $(10 \mathrm{~mm})$ for jaws. 
anteroconid (morphotype $\mathrm{V}$ in adult specimens, flattened and with shallow anteroflexid in juvenile individuals) is very short (about $1 / 4$ of tooth length). The protoflexid walls form a right angle. The paraflexid is present, shallow in adults, more marked in juveniles. In adult specimens the hypoflexid is longer than the mesoflexid (medially with a bilobed tip), whereas in juveniles they have approximately the same depth. In adult specimens these two flexids are quite shallow, and therefore the isthmus connecting the trigonid and talonid is very wide (about $20 \%$ of tooth width). The posterior wall of both flexids is crenulated in 1 of 3 specimens (in specimen 4976 the enamel wall is not recognizable). In the medial part of the hypoflexid morphotype "A" predominates. The labial side of the hypoconid varies from morphotype "c" to "d".

Lower molariforms: No small reentrant is present at the antero-buccal corner of the trigonids of p4-m2; the anterior wall of the talonids is smooth.

Maxilla: The only available specimen (No. 4998) consists of two isolated upper jaws glued together (Fig. 3H1), thus no structures in the palatal bridge are recognizable. Both masseteric spines are broken.

P2: The hypercone has a very simple morphology and lacks a hypoflexus (morphotype II). An incipient mesoflexus is present in the lagicone (morphotype A).

Upper molariforms: The internal reentrant extends across approximately $2 / 3$ the tooth width and is slightly crenulated on both sides.

Measurements. - Mandible (4976, 4977, 4978, 4979): alveolar length of p3-m3 = 14.39, 14.71, -, -; diastema length $=18.01,18.05,-,-$; height at p3 $=12.37,12.65,-,-$; p3 $(\mathrm{LxW})=3.10 \times 2.95,3.10 \times 2.85,2.60 \times 2.35,2.65 \times$ 2.35; maxilla (4998): alveolar length of P2-M3 = 16.19; $\mathrm{P} 2$ (sin, dex): $\mathrm{L}=1.50,1.50 ; \mathrm{W}=3.05,3.25$.

\section{Alilepus turolensis López Martínez, 1977}

Type series. - The type series (Articles 72.1.1 and 72.4.1) consists of 2 p3s and 1 P3 from El Arquillo and 1 P2, 1 M1 and 1 D3 from Los Mansuetos. The nominal taxon Alilepus turolensis was fixed in López Martínez (1977, p. 20) by a holotype (sensu Article 73.1.1 of ICZN 1999).

Name-bearing type. - Holotype - left p3 (ARQ-64); collections of the UM2.

Type locality and age. - El Arquillo (Rambla de Valdecebro 2), Spain; Late Turolian, MN13.

Description of the type material. - See López Martínez (1977).
Measurements. - p3 (holotype): $\mathrm{L}=3.41, \mathrm{~W}=2.98$; additional material of type series: p3 (ARQ-65): $\mathrm{L}=-, \mathrm{W}=$ 2.86.; P2 (LM-1001): L = 1.49, W = 3.30; M1 (LM-1002): $\mathrm{L}=2.23, \mathrm{~W}=-; \mathrm{D} 3(\mathrm{LM}-1003)$ : L= -, W = 1.72; (after López Martínez 1989).

\section{Alilepus meini Angelone \& Rook, 2011}

Type series. - Only the holotype (conforming Articles $16.4,72.3$ and 73.1 of ICZN 1999), without paratypes, was designated.

Name-bearing type. - Holotype - right p3 (IGF 9320v); collections of the UFM.

Type locality and age. - Ribardella (Baccinello-Cinigiano basin), Italy; Late Turolian, MN13.

Description of the type and of additional material. - See Angelone \& Rook (2011).

Measurements. $-\mathrm{p} 3$ (holotype): $\mathrm{L}=2.65, \mathrm{~W}=2.58$ (occlusal side); $\mathrm{L}=3.00, \mathrm{~W}=2.54$ (radical side); additional material from the type locality: lower molariform (IGF 3222v): $\mathrm{L}=2.71$; lower molariform $(\mathrm{IGF} 3223 \mathrm{v}): \mathrm{L}=2.65$, Wtrig $=$ 3.04; P3 (IGF 9321v): L $=2.21$, Wpost $=4.35$.

\section{Systematic palaeontology}

Order Lagomorpha Brandt, 1855

Family Leporidae Fischer, 1817

\section{Genus Alilepus Dice, 1931}

Type species. - Lepus annectens Schlosser, 1924, by original designation.

Original diagnosis. - See Dice (1929, p. 342).

Emended diagnosis. - See White (1991, p. 69).

Nomenclatural note and lectotype designation of Lepus annectens. - The genus fixed by the type species Lepus annectens Schlosser, 1924, was first erected by Dice (1929) under the generic name Allolagus. However, the name Allolagus was preocupied by Allolagus Ognev, 1929 with type species Lepus mandshuricus Radde, 1861. Subsequently, Dice (1931) erected Alilepus as a new replacement name. The nominal taxon of the type species was established by Schlosser (1924) based on the syntype (Article 73.2 of ICZN 1999) from Ertemte and Olan Chorea (Schlosser 1924, p. 45). No single 
name-bearing type specimen has been designated till now.

The vast majority of syntype comes from Ertemte [1] discovered in 1919 by J.G. Anderson and excavated intensively in 1919 and 1920. Additional abundant leporid material from that area, about $400 \mathrm{~m} \mathrm{SSW}$ of the original Anderson's locality, was recovered in 1980 from Ertemte 2 (Fahlbusch et al. 1983, Qiu 1987). Fossils from both localities, Ertemte [1] and 2, most probably belong to the same horizon and age, the Late Turolian, MN13 (Fahlbusch et al. 1983). Nevertheless only the original material published by Schlosser (1924) has nomenclatural relevance. The original material from Olan Chorea comprises only four fragments of postcranial bones not allowing a clear species attribution. Moreover, Olan Chorea appears to be younger than Ertemte [1] (Qiu 1987).

Due to the above, there is a need to fix a nominal taxon by a single name-bearing specimen. Thus, in the sense of Articles 74.7 and 74.4 and Declaration 44, we hereby designate the right mandible with $\mathrm{p} 3-\mathrm{m} 2$ figured (Article 74.4) in Schlosser (1924, pl. III, figs 37, 37a; Article 74.7.2) as a lectotype (Article 74.7.1 and Declaration 44) of the nominal taxon of Lepus annectens Schlosser, 1924, described from the Late Miocene (MN13) locality Ertemte [1].

\section{Alilepus laskarewi (Khomenko, 1914)}

Figures 4I1-R, T, V, X, 5

\section{Locality and age. - Egorovka 2 (UA); MN12.}

Referred material and measurements. -3 p $3 \sin , \mathrm{L}=2.98$, $2.69,2.63$ (juv.), $\mathrm{W}=2.62,2.88,2.39$ (juv.); 3 p3 dex, $\mathrm{L}=$ 2.69 (juv.), 2.91, 2.93, W = 2.71 (juv.), 2.66, -; P2 dex (juv.), $\mathrm{L}=1.48, \mathrm{~W}=2.82 ; \mathrm{d} 3 \sin , \mathrm{L}=1.83, \mathrm{~W}=1.60$; tal $\mathrm{p} 4$ dex, Wtal $=2.55 ; \mathrm{p} 4$ dex, $\mathrm{L}=2.39$, Wtrig $=2.66$, Wtal $=$ 2.16; $\mathrm{m} 2 \sin , \mathrm{L}=2.40, \mathrm{~W}$ trig $=2.85$, Wtal $=2.24 ; \mathrm{m} 3 \mathrm{dex}$, $\mathrm{L}=1.87$, Wtrig $=1.79$, Wtal $=1.08$; trig $\mathrm{p} 4$ sin, Wtrig $=$ 2.89; frag tal $\mathrm{m} 1 \mathrm{dex}$; trig $\mathrm{m} 2$ dex, Wtrig $=2.69$; i1 $\sin$ (juv.); tal p4 sin, Wtal = 2.04; I1 sin, $\mathrm{L}=1.83, \mathrm{~W}=2.70$, $\mathrm{Wg}=1.23$; $\mathrm{P} 4$ or $\mathrm{M} 1 \sin , \mathrm{L}=2.26$, Want $=3.78$, Wpost $=$ 3.86; M3 dex; $\mathrm{L}=0.94, \mathrm{~W}=1.56 ; 5$ fragments of upper molariforms; fragment of masseteric spine; rostral part of sin and dex premaxillas; proximal part of radius; fragment of pelvis; talus; medial part of shaft of radius (NMNHU Egr-2-101-131).

Description. - p3: The available specimens are divided equally among morphotype $\mathrm{PR} 1 / \mathrm{A} 0 / \mathrm{Pa} 0(\mathrm{~N}=3)$ and morphotype $\mathrm{PR} 2 / \mathrm{A} 0 / \mathrm{Pa} 0(\mathrm{~N}=3)$. In all specimens the pattern of $\mathrm{p} 3$ is stable along the entire tooth crown (Fig. 4I1-N2). The anteroconid length ranges from $26 \%$ to $35 \%$ of total $\mathrm{L}$ $(\mathrm{N}=6)$ and in some cases the anteroconid is widened lingually. Morphotypes I/II, II and IV are present. The protofle- xid is shallow. Its depth varies from $8 \%$ to $15 \%$ of the tooth width (averaging $11 \% ; \mathrm{N}=5$ ), with the angle formed by its walls ranging from a right to obtuse angle. The hypoflexid crosses on average $47 \%$ of the occlusal surface (ranging from $44 \%$ to $50 \% ; \mathrm{N}=5$ ), and is straight and horizontal. The medial part of the hypoflexid is variable within the sample, with morphotypes ranging from " $A$ " to " $D$ ". In the hypoconid morphotypes "b", "c" and "e" are observed, with "e" predominant. In one specimen (Fig. 4K1, K2), the anterior wall of the hypoconid is deeply infolded. The mesoflexid is shallow, in general shallower than the hypoflexid, and with a simple labial end. When present (50\% of individuals), the mesofossettid is irregularly oval, very large, with the lingual end almost reaching the tooth edge. The connection between trigonid and talonid is wide to very wide. Only in one specimen (Fig. 4K1, K2) is the protoisthmus narrow. There can be a very shallow paraflexid, in one case filled with cement.

d3: The tooth (Fig. 4O1, O2) is in an early stage of abrasion. It has the typical trilobed appearance of a juvenile. The buccally shifted anteroconid has a widened tip with a depression. The protoflexid is deep and its walls form an acute angle. A shallow concavity (paraflexid?) is present in the lingual border, between the anteroconid and trigonid. The talonid is hatchet-shaped with smooth enamel borders and indented by a notch on both sides.

Lower molariforms (Fig. 4P1-R): The trigonid is longer than the talonid. Neither a reentrant at the antero-buccal corner, nor a tip on their posterior side is present on the trigonids. The anterior and antero-buccal walls of the talonids range from smooth to moderately crenulated and a small antero-buccal reentrant is present.

P2: In the only specimen (Fig. 4V) the hypoflexus is not present (morphotype II), whereas an incipient mesoflexus is present (morphotype A). The paraflexus reaches half the tooth length.

Upper incisor (Fig. 4T): In cross section the first upper incisor is approximately rectangular. Its anterior enamel is thin. The groove on the anterior surface is simple with widely opened walls and is not filled with cement. The groove is located near the middle of the crown.

Upper molariforms: The hypostria is mildly to strongly crenulated on both sides and enters about $60 \%$ of the tooth.

Emended diagnosis. - Small-sized leporid; p3 of PR1/A0/Pa0 (slightly predominant) or $\mathrm{PR} 2 / \mathrm{A} 0 / \mathrm{Pa} 0$ morphotype, with long (about $1 / 3$ of tooth length) morphologically variable anteroconid, shallow and wide protoflexid (about $10 \%$ of tooth width), wide connection between trigonid and talonid, short (less than $50 \%$ of tooth length) morphologically variable (morphotypes A to D) hypoflexid; anterior and antero-buccal walls of $\mathrm{p} 3-\mathrm{m} 2$ talonids ranging from smooth to moderately crenulated, $\mathrm{p} 4-\mathrm{m} 2$ trigonid without 
antero-external reentrant; incisors with thin enamel, I1 without cement; P2 of simple morphology (II/A morphotype) with short paraflexus; P3-M2 hypostria short (about 60\% of tooth width), mildly to moderately crenulated.

Stratigraphic and geographic distribution. - The proven record from the Late Turolian (MN12) of Ukraine and Moldova.

Comparison. - The attribution of the leporids from Egorovka 2 to the genus Alilepus is fully compatible with the diagnosis of the genus proposed by White (1991). The similarities between the Alilepus from Egorovka 2 and the lectotype of A. laskarewi from Tarakliya, the same age (MN12) and the close geographical proximity ( ca $100 \mathrm{~km}$ ) of these localities, justify the ascription of the leporid from Egorovka 2 to A. laskarewi.

The very high incidence of the mesofossettid (50\%, similar incidence as presence of a mesoflexid) together with unilobated anteroconid on $\mathrm{p} 3$, discriminate this Late Miocene leporid from all other known Late Miocene and Pliocene Alilepus recorded from Europe and Asia. In addition to these characters, Alilepus laskarewi differs from:

1) A. hungaricus and A. ucrainicus in its p3 with relatively longer, anteriorly rounded and less wide anteroconid as well as shorter talonid; P2 with shorter paraflexus (compared to A. ucrainicus); lower molariforms with anterior walls of talonids more crenulated.

2) A. turolensis and A. meini in its p3 with longer anteroconid, much shallower, obtuse-angled protoflexus, much wider connection between trigonid and talonid, and straight entoconid; moreover, the p3 of A. meini is more crenulated.

3) Alilepus annectens (Schlosser, 1924) described from the Late Miocene (late Baodean, NMU 11, i.e., comparable to the Late Turolian (MN13) in Europe [Fejfar et al. 2011; cf.e.g., Fahlbusch et al. 1983, Qiu \& Qiu 1995, Flynn et al. 1997, Qiu et al. 1999, Deng 2006]) Ertemte and Olan Chorea localities (Inner Mongolia, China) in its significantly smaller size and more developed posterointernal structures on $\mathrm{p} 3$; in A. annectens (based on the material from Ertemte [1] and 2; Schlosser 1924, Fahlbusch et al. 1983, Qiu 1987) the mesoflexid never extends more than about one-third of the tooth width, and the mesofossettid, if present (14\% of cases, $\mathrm{N}=14$; material from Ertemte 2, Qiu 1987), is smaller and more gracile; the available lower and upper molariforms are less crenulated; the anteroconid of p3 is less variable in general shorter and of morphotype II.

4) A. longisinuosus Qiu \& Han, 1986, described from the Late Miocene Lufeng locality, Yunnan, China (currently estimated at 6.6-6.2 Ma [Qi et al. 2006]; i.e., late Baodean, NMU 11) in its smaller average size and its wider connection between trigonid and talonid. Alilepus longisinuosus has a significant tendency for reduction of the connection between the trigonid and talonid on p3 (very weak in $15 \%$, absent in $18 \%, \mathrm{~N}=34$; Qiu \& Han 1986) there is a presumed morphocline A0/PR1 $\Rightarrow$ A0/PR4. Alilepus longisinuosus commonly has a long hypoflexid (morphotype A0/PR3, probably derived from A0/PR2), rarely a mesofossettid (6\%, N = 34; Qiu \& Han 1986); talonids of lower teeth with less crenulated anterior walls, and P2 with larger, better-developed mesoflexus.

5) Alilepus lii Jin, 2004, known from a single mandible with p3-m1 from the latest Miocene (Late Baodean, NMU11; Deng 2006) deposits of Laodong Cave (Huainan, Anhui Province, China), for its larger anteroconid and less crenulated anterior walls of talonids in lower teeth.

6) Alilepus elongatus Winkler, Flynn \& Tomida, 2011, from the Late Miocene (Middle Turolian, MN12, 7.35-6.5 Ma) deposits of Dhok Pathan Formation (Siwalik Group, Potwar Plateau, Pakistan) in its smaller size, wider but antero-posteriorly less elongated anteroconid, wider connection between trigonid and talonid, shorter mesoflexid, less crenulated hypo- and mesoflexid; absence of anteroexternal reentrant on the trigonid in all lower molariforms.

Remark. - A comparison with the material from the Early Pleistocene deposits of Zhoukoudian Cave (China) described by Cheng et al. (1995a, b) as Alilepus zhoukoudianensis was impossible due to lack of sufficient published data (Angelone \& Rook 2011).

\section{Alilepus cf. hungaricus Kormos, 1934}

Figure 4A-B2, F, G

Referred material and measurements. - Andreevka (UA), MN13 (NMNHU 33-1457-NMNHU 33-1464): p3 dex, $\mathrm{L}=3.06, \mathrm{~W}=2.82 ; \mathrm{p} 3 \sin , \mathrm{L}=2.91, \mathrm{~W}=2.87$; $11 \sin , \mathrm{L}=$ $2.35,2.31, \mathrm{~W}=2.86,3.09 ; \mathrm{m} 2 \mathrm{sin}, \mathrm{L}=2.54$, Wtrig $=2.96$, $\mathrm{Wtal}=2.46$; trig $\mathrm{m} 1 \mathrm{dex}, \mathrm{W}$ trig $=3.01$; trig $\mathrm{m} 2 \mathrm{dex}$, Wtrig $=2.97 ; \mathrm{P} 3 \sin , \mathrm{L}=2.23$, Want $=3.42$, Wpost $=3.96$.

Description. - p3 (Fig. 4A-B2): Adult individuals display the $\mathrm{A} 0 / \mathrm{PR} 1 / \mathrm{Pa} 0$ morphotype, maintained along the entire crown; a relatively short anteroconid ( $\sim 30 \%$ of tooth length in adults) markedly widened lingually; protoflexid with rightangled walls; the hypoflexid ("B" morphotype in its medial part) slightly indents the talonid and is crenulated in its distal side; the labial end of the mesoflexid is simple (not bilobed); the connection between trigonid and talonid is relatively wide; the labial part of the hypoconid is of "c" morphotype.

Lower molariforms (Fig. 4G): Ltri > Ltal; the reentrant at the antero-buccal corner of the trigonid is not present. The trigonid appears labially prominent and rounded. In the talonid (available only in $\mathrm{m} 2$ ), the anterior wall is slightly undulated and a small antero-buccal reentrant is present. 




Figure 4. Leporid teeth from the Late Miocene (MN11-13) of Ukraine and Moldova. • A-B2, F, G-Alilepus cf. hungaricus, Andreevka; A - right p3 (NMNHU 33-1457); B1, B2 - left p3 (NMNHU 33-1458), occlusal and radical views; F - left i1 (NMNHU 33-1459); G - left m2 (NMNHU 33-1461). - C-E2, H - Alilepus sp., Novoukrainka 1; C - right p3 (NMNHU 38-2066), cross-section (radical view); D - left p3 (NMNHU 38-2067), cross-section (radical view); E1-E2 - right d3 (NMNHU 38-2068), occlusal and buccal views; H - left m1 (NMNHU 38-2066). I1-R, T, V, X - Alilepus laskarewi, Egorovka 2; I1, I2 - left p3 (NMNHU Egr-2-101), occlusal and radical views; J1, J2 - right p3 (NMNHU Egr-2-102), occlusal and radical views; K1, K2 - right p3 (NMNHU Egr-2-103), occlusal and radical views; L1, L2 - left p3 (NMNHU Egr-2-104), occlusal and radical views; M - occlusal view of right p3 (NMNHU Egr-2-105); N1, N2 - left p3 (NMNHU Egr-2-106), occlusal and radical views; O1, O2 - left d3 (NMNHU Egr-2-108), occlusal and radical views; P1, P2 - talonid of right p4 (NMNHU Egr-2-109), occlusal and radical views; Q - right p4 (NMNHU Egr-2-110), occlusal view; $\mathrm{R}$ - left m2 (NMNHU Egr-2-111), radical view; T - left I1 (NMNHU Egr-2-118), cross-section; V - right P2 (NMNHU Egr-2-107), occlusal view; X - left P4/M1 (NMNHU Egr-2-119), occlusal view. • S1, S2, U, W - Alilepus sp., Cherevichnoe 3; S1, S2 - left D3 or D4 (NMNHU 45-5955), occlusal and rostral views; U - left I1 (NMNHU 45-5952), occlusal view; W - right P3 (NMNHU 45-5953), occlusal view. • Y-Z - ?Alilepus sp., Palievo; Y - right $\mathrm{m} 1$ (NMNHU Plv-03), cross-section (radical view); Z - left P4 or M1 (NMNHU Plv-04), occlusal view. • A*, B* - ?Alilepus sp., Keinar (MD); 2 left upper molariforms (FGTU 1-2 Lag/Knr), occlusal views. 
i 1 (Fig. 4F): Trapezoidal shape, thin enamel on anterior part.

P3: Damaged and the only specimen; the hypostria is mildly crenulated on both sides.

Remarks. - The scarce material from Andreevka does not allow a definite specific determination; however, the dental features of $\mathrm{p} 3$ and the lower molariforms (e.g., relatively short and markedly lingually widened anteroconid [morphotypes II and III] and the undulated anterior enamel of the hypoconid in p3, plus the labial shape of the trigonid and its relative proportions to the talonid) are compatible with the name-bearing type of Alilepus hungaricus. The age (MN13) of these specimens also supports their ascription to A. hungaricus. However, as shown above, the intraspecific variability of Late Miocene Alilepus from that area is very high, and the above-mentioned features may not represent dominant morphotypes in the population. Moreover, A. hungaricus is known only from its type material. Thus, until further relevant material of Alilepus from Andreevka is available, we refer this material tentatively to Alilepus cf. hungaricus.

\section{Alilepus sp.}

Figure 4C-E2, H, S1-2, U, W

Referred material and measurements. - Cherevichnoe 3 (UA), MN12 (NMNHU 45-5951-45-5956): fragm. p3 dex; I1 sin, $\mathrm{L}=1.84, \mathrm{~W}=2.65, \mathrm{Wg}=1.07 ; \mathrm{P} 3$ dex, $\mathrm{L}=$ 2.16, Want $=3.34$, Wpost $=4.14 ; \mathrm{P} 4$ or $\mathrm{M} 1, \mathrm{~L}=2.23$, Want $=3.52$, Wpost $=3.64 ; 2$ D3 or D4 $\sin , \mathrm{L}=1.53,1.50$, Want $=2.03,2.13$, Wpost $=2.33,2.27$. Novoukrainka 1 (UA), MN13 (NMNHU 38-2066-38-2074): p3 dex (fragm.); p3 sin (fragm.); d3 dex, $\mathrm{L}=2.00, \mathrm{~W}=1.52 ; \mathrm{m} 1$ $\sin , \mathrm{L}=2.56$, Wtrig $=2.71$, Wtal $=2.23 ; \mathrm{m} 2$ dex (?juv.), $\mathrm{L}=2.23$, Wtrig $=2.49$, Wtal $=1.83 ; \mathrm{P} 4$ or $\mathrm{M} 1$ dex, $\mathrm{L}=$ 2.18, Want $=3.61$, Wpost $=3.63 ; 2$ upper molariforms; I1 dex (juv.).

\section{?Alilepus sp.}

Figure $4 \mathrm{Y}-\mathrm{B}^{*}$

Referred material and measurements. - Keinar (MD), MN11 (FGTU 1-2 Lag/Knr): 2 upper molariforms sin. Palievo (UA), MN11 (NMNHU Plv-03, 04): m1 dex, L = 2.87 , Wtrig $=3.14$, Wtal $=2.42 ; \mathrm{P} 4$ or $\mathrm{M} 1 \sin , \mathrm{L}=2.25$, Want $=3.55$, Wpost $=3.58$. Kubanka 2 (UA), MN12 (NMNHU Kbn-2-01): I1 sin, $\mathrm{L}=1.49, \mathrm{~W}=2.58, \mathrm{Wg}=$ 1.67. Tretya Krucha 2 (UA), MN12 (NMNHU TKr-1-01): fragment of upper molariform.

Remarks. - The scarce material from Cherevichnoe 3, No- voukrainka 1, Keinar, Palievo, Kubanka 2 and Tretya Krucha 2 does not include sufficient diagnostic features and therefore is inadequate to confidently assign specimens to species or even to genus. The large age span of these findings, ranging from MN11-13, may support the presence of more than one species.

\section{Discussion}

\section{The new Ukrainian and Moldovan leporids in the context of the most ancient Old World records}

The appearance of Leporinae in Eurasia, and somewhat later in Africa, is a result of the Late Miocene migration from North America via the northern land connection of Beringia (López Martínez 2008 and references therein). Until the Late Miocene, there is no proven record of leporines in $\mathrm{Eu}-$ rope ( $c f$. Boon-Kristkoiz \& Kristkoiz 1999). The relatively rapid spread of leporids across the Old World around $8 \mathrm{Ma}$ was an important Turolian event and is called the "Leporid Datum" (Flynn et al. 2014). Whereas MN12 Old World records of Leporinae are relatively rare, and mostly limited to Europe, MN13 ones are relatively more common and available throughout the Old World. Only few, very fragmentary findings, date an appearance of advanced leporids in the Old World undoubtedly before MN12 (Flynn et al. 2014). There are also a few, still questionable fossil occurrences suggesting that leporids were present in Europe prior to MN11, however in many of these cases the relation of the leporid findings with the accompanying faunal assemblages is not clear and such findings need further evaluation of both age and taxonomy (see Flynn et al. 2014).

In the Late Miocene, Old World leporids already show a high phenotypic/taxonomic diversity. Four Archaeolaginae and Leporinae genera are recorded:

1) Alilepus: proven from MN12 (Flynn et al. 2014 and references herein);

2) Hypolagus Dice, 1917: proven from MN13 (Averianov 1996, Čermák 2009);

3) Pliopentalagus Gureev \& Konkova in Gureev, 1964: proven from late MN13 (Tomida \& Jin 2009);

4) Trischizolagus Radulesco \& Samson, 1967: from ?MN13 (with PR0/A1/Pa0 morphotype), however the Late Miocene appearance of Trischizolagus is very poorly recorded and still remains questionable (López Martínez et al. 2007, Čermák \& Wagner 2013).

Alilepus laskarewi represents the first-available described species of the Old Word Alilepus, originally described as Lepus laskarewi. Nevertheless, since Khomenko's (1914) publication the phenotype considerations and species attributions have been made only based on insufficient species description and poorly figured type spec- 
imens by Khomenko (1914), (e.g., cf. Kormos 1934; Gureev 1964; Radulesco \& Samson 1967; López Martínez 1977, 1989; Angelone \& Rook 2011; Winkler et al. 2011). At any rate, the type specimen (here designated as lectotype) possesses the typical Alilepus PR1/A0 morphotype, as seen in all published Alilepus European reports.

The new material of Alilepus from the MN12 locality Egorovka 2 shows a different $\mathrm{p} 3$ phenotype than presumed. A very high incidence of the PR2/A0 morphotype (= presence of mesofossettid) in $\mathrm{p} 3$ changes the view on the phenotype distribution in the earliest European Leporinae. In fact the "primitive" phenotype of leporines was thought to be the "classic" European Alilepus morphotype PR1/A0 (cf. Hibbard 1963, Averianov \& Tesakov 1997). The p3 phenotype in the material from Egorovka 2 cannot be looked upon as exceptional or an accidental sampling of extreme morphotypes. A presence of PR2/A0 morphotype in Alilepus has been mentioned (without any further discussion) in a very recent paper by Delinschi (2014) from another MN12 locality, Chimishliya (situated in the close vicinity of the type locality Taracliya). Egorovka 2 and Chimishlyia are coeval and situated in the presumed "terra typica" of A. laskarewi. Thus the high incidence of $\mathrm{p} 3$ mesofossettid in MN12 populations of Alilepus seems to be characteristic of the northwestern part of Eastern Paratethys.

\section{Taxonomical notes on Alilepus species in Europe}

Dice's (1931) original description, followed Schlosser (1924), discriminating the taxon based on $\mathrm{p} 3$ consisting "of two columns connected in the centre of the tooth by a bridge of dentine". The emended diagnosis by White (1991, p. 69), based on comprehensive revision of Alilepus from the late Miocene to Pliocene of North America, indicates a presence of mesofossettid in some Alilepus populations. The attribution of the newly described Late Miocene Ukrainian leporid populations to the genus Alilepus is fully compatible with the diagnosis proposed by White (1991).

As shown in "Systematic palaeontology" Alilepus laskarewi is a well-documented species, clearly discriminated from other European species. Its most peculiar distinctive trait is the high incidence of PR2/A0 morphotype in p3. This is in contrast with other European species, which show exclusively a p3 with clear A0/PR1 morphotype. Size relationships of $\mathrm{p} 3 \mathrm{~s}$ among Alilepus laskarewi, name-bearing specimens of European Alilepus species and leporines from the Early Pliocene (MN14-15) of Central and Eastern Europe is shown in Fig. 5.

Alilepus hungaricus, known only from its type locality Polgárdi 2 (MN13), seems to be differentiated by its short-

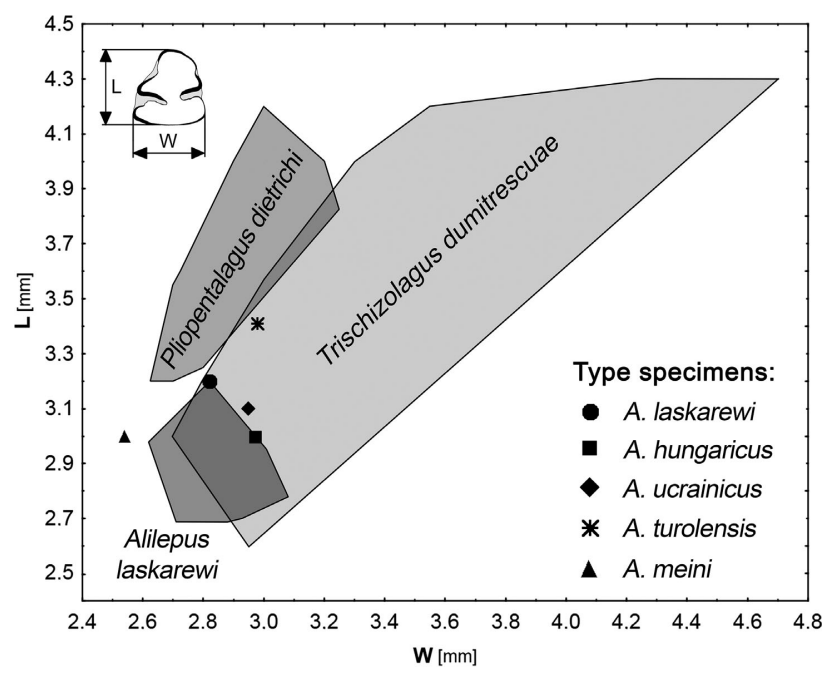

Figure 5. The p3 length-to-width scatterplot showing the size relationship among (1) Alilepus laskarewi (Egorovka 2, UA and Chimishliya, MD), (2) name-bearing specimens of European Alilepus species (A. laskarewi - Tarakliya, MD; A. hungaricus - Polgárdi 2, HU; A. ucrainicus - Odessa Catacombs, UA; A. turolensis - El Arquillo, ES [data from López Martínez (1977)]; and A. meini - Ribardella, IT) and (3) leporines from the Early Pliocene (MN14-15) of Central and Eastern Europe; i.e., (a) Trischizolagus dumitrescuae (Beremend 39, HU; Berești, RO; Ciuperceni 2, RO; Grebeniki 2, UA; Lucheshty, MD; Mălușteni, RO; Megalo Emvolon 1, GR; Moskovei, MD; Muselievo, BG; Nikolskoe, MD; Novaya Andriashevka, MD; Stavnichevo, UA; Tatareshty, MD) and Pliopentalagus dietrichi (Budăi, MD; Ivanovce, SK; and Muselievo, BG), data from Čermák \& Wagner (2013) and references therein.

ened and lingually widened p3 anteroconid and probably also the less crenulated anterior walls of talonids in lower molariforms. These features of A. hungaricus are in a good correspondence with those of Alilepus from Andreevka (MN13), described here as Alilepus cf. hungaricus. Nevertheless, based on the available material and, taking into account palaeoecological peculiarities of the Pannonian area, a relation of Alilepus from Andreevka to A. hungaricus cannot be fully resolved now and remains unclear. It is noteworthy that in the MN10/11 lokality Csákvár, a few kilometers away from the type locality of A. hungaricus, Kretzoi (1954, p. 47; $c f$. Rabeder 1989) mentions the presence of "Lagomorpha indet. (Alilepus?)". This identification was based on a fragment of long bone bearing no features attributable to Alilepus, not even to a leporid (SČ pers. obs.; MFGI 2013).

Alilepus ucrainicus from Odessa Catacombs (MN15b) is peculiar among other Alilepus species not only in its unusually formed anteroconid, but also in its distinctively younger age. The presence of the A0/PR1/Pa0 morphotype in p3 (in the verifiable cases - expressed along the entire crown) and relatively simple $\mathrm{P} 2$ support attribution to Alilepus. Note, however that incipient presene of an anteroflexid (as a depression), together with separation of the anteroconid from the rest of trigonid, are rarely present 
also in Trischizolagus (particularly in subadult specimens). Trischizolagus is the leporid that dominated the area during the Pliocene (Čermák \& Wagner 2013). On the other hand, crenulation of anterior walls of the talonids in lower molariforms (see p3, No. 4977; Fig. 3E2) would be very atypical for Trischizolagus. The available material does not provide a conclusive argument for an attribution to Trischizolagus, so attribution to a separate species of Alilepus is retained in this paper.

Alilepus turolensis is reported from some MN12-13 central-eastern Spanish localities (MN12; López Martínez 1977, 1989). Alilepus sp. from the MN13 of Lissieu (France; Mein 1988, 1999) likely pertains to this species. The very thin connection between the trigonid and talonid and the narrow protoflexid, that distinguish A. turolensis, characterize also the remains from the NE Greece localities Maramena (MN13) and Pikermi (MN12). Material from these localities was, respectively, classified as A. turolensis and Alilepus sp. by de Bruijn (1995) and López Martínez (1976). Taking into account the palaeobiogeographical context of such scanty material, a species determination of Greek Alilepus is unclear and needs further taxonomical evaluation based on additional material. Another Greek record (MN10-11, Elaiochoria 2; Hulva et al. 2007) is here excluded as it bears distictive non-Alilepus features (SČ pers. obs.; GLI 2013).

Alilepus meini is known exclusively from its type locality, a geographically restricted area in central-western Italy in which lived several other continental isolated species of vertebrates together with "normal" taxa of wider European affinity (Angelone \& Rook 2011 and references therein). Its morphological features reveal its affinity with $A$. turolensis, constituting a group distinct from the rest of European species.

\section{The mesofossettid in Leporinae: Old vs New World}

Postero-internal structures in p3 are a very important part of the tooth phenotype in Leporinae (Hibbard 1963, White 1991, Averianov \& Tesakov 1997, López Martínez et al. 2007). These structures are never well developed in the sister clade to Leporinae, the Archaeolaginae. The oldest representatives of the Leporinae are recorded from the Middle Miocene (Late Barstovian, ca Late Astaracian; Late MN6, ca $13 \mathrm{Ma}$ ) of the Valentine Railway Quarries (Nebraska, USA). These specimens have a PR0/A0 morphotype with incipient para- and/or mesoflexid (/mesofossettid), and are generally referred to the genera Alilepus or Pronotolagus White, 1991 (Voorhies \& Timperley 1997). Among these earliest representatives, a small mesofossettid was documented in two p3 (both of PR0/A0) from Stewart Quarry (the site of the Valentine Railway Quarries) referred by Voorhies \& Timperley (1997) to Alilepus sp.
(Fig. 6). In one specimen (UNSM 117079), the mesofossettid was most probably derived from the mesoflexid, but in the other (UNSM 117069) the mesofossettid, adjacent to the lingual end of hypoflexid, seems to be derived from this structure or even independently. One of the six p3 of Alilepus hibbardi White, 1991, reported by White (1991) from the early Late Miocene (Late Clarendonian; ca MN10 equivalent) of California and Nevada (USA), possesses a small mesofossettid (p3 with PR2/A0). Taking into account its position near the lingual portion of tooth, a derivation from a weakly developed mesoflexid is likely.

The classical well-developed mesofossettid of North American Leporinae is documented from the Early Blancan in A. vagus Gazin, 1934 (Pratilepus sensu Hibbard, 1969; see White [1991] for arguments supporting the attribution to Alilepus), Pratilepus kansassensis Hibbard, 1939a and Nekrolagus progressus (Hibbard, 1939b). In all these taxa the PR2 p3 morphotype is clearly predominant (Fig. 6; Hibbard 1963, 1969; White 1991; White \& Morgan 1995). In the latest Hemphillian ( $c a$ latest Turolian, MN13) in specimens assigned to A. vagus from Santee (Nevada) and $N$. progressus from the Upper Bone Valley (Florida), the presence of a mesofossettid was not documented ( $c f$. White 1991, White \& Morgan 1995). During the Blancan (ca Pliocene) a well-developed mesofossettid appeared also in Aztlanolagus Russell \& Harris, 1986 (the structure shows a constant occurrence at $100 \%$ through time till the Late Rancholabrean [ca late Pleistocene]; Tomida 2008), Aluralagus Downey, 1968 and Sylvilagus. In all these Blancan forms the mesofossettid, if presents, is generally large and oval medio-lingually (Fig. 6).

A "closed enamel structure" (CES) may also appear in forms close to Paranotolagus Miller \& CarranzaCastaneda, 1982 (p3 LACM106768 of ?Paranotolagus from the middle Blancan [ca Early Villányian], La Goleta locality, Mexico), but it is projected more anteriorly. The presence of this CES is most likely a result of the extreme development of the paraflexid, as in Notolagus Wilson, 1938 (cf. White 1991). A similar development of CES was documented by Russell \& Harris (1986; Fig 2A, specimen MNM 5689-98-1) in the late Pleistocene records of Aztlanolagus agilis. The CES in these two taxa has nothing to do with the mesofossettid, which is related to posterointernal structures of $\mathrm{p} 3$.

In extant American taxa, the mesofossettid aberrantly/rarely appears in taxa such as Sylvilagus audubonii, S. aquaticus, Lepus californicus and L. americanus. Extremely large mesofossettids are observable in Romerolagus diazi.

The situation is different in the Old World fossil record, where the Late Miocene - Pliocene Leporinae are less diversified. The oldest Old World evidences of frequently occurring mesofossettid in p3 are documented from the middle-late MN12 of northwestern peri-Paratethyan area 


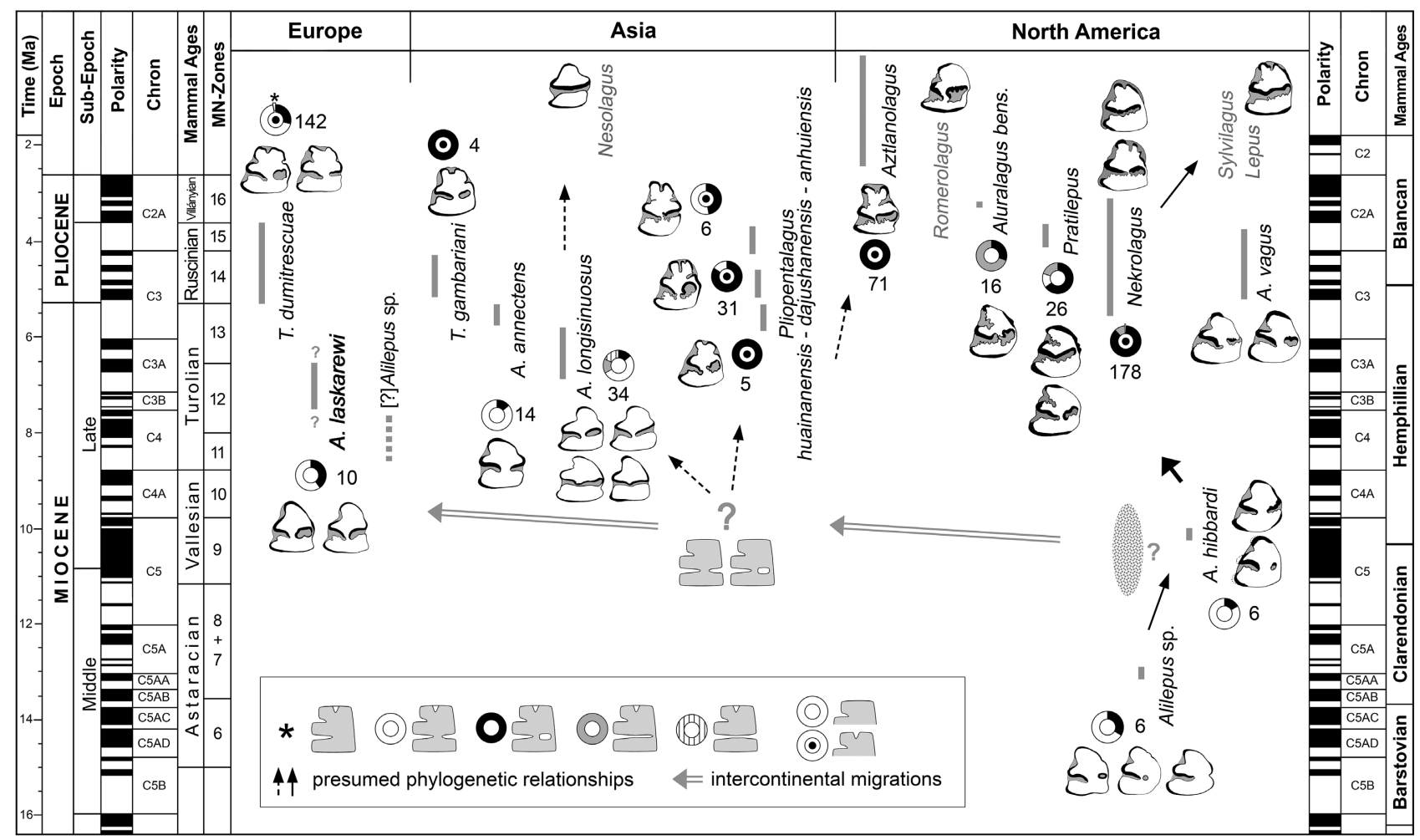

Figure 6. Distribution and diversity of p3 mesofossettid in Leporinae of North America and Eurasia with presumed phylogenetic relationship of selected taxa. For each species the circular symbol with number illustrates the p3 morphotype distribution and the number of specimens included. The vertical grey bar shows the stratigraphic span (data, p3 drawings and biostratigraphic chart from this paper and references herein). The recent genera are written in grey.

(i.e., A. laskarewi; Fig. 6). For its size and position this structure is comparable to similar structures documented in North American Blancan findings of Alilepus vagus, or in the more morphologically derived species Nekrolagus progressus and Pratilepus kansansiensis.

The rare presence of a mesofossettid can be observed also in Alilepus longisinuosus from the Late Miocene (MN12/13) of Lufeng (Yunnan, China), that should be coeval or possibly slightly younger (Qi et al. 2006) than the peri-Paratethyan findings. Nevertheless this Asiatic form is clearly distinct from A. laskarewi and most probably belongs to a lineage evolving separately from other known Alilepus taxa (see below). The sporadic presence of a mesofossettid in Alilepus annectens from Ertemte (MN13) represents a clearly younger evidence of this structure (Fig. 6).

Among Asiatic Late Miocene-Pliocene leporid taxa the mesofossettid shows a high incidence only in the peculiar genus Pliopentalagus, whose earliest record dates back to the latest Miocene of Laodong Cave locality (China). It is noteworthy that within the latest Miocene-Late Pliocene lineage $P$. huainanensis Jin, $2004-P$. dajushanensis Tomida \& Jin, 2009 - P. anhuiensis Tomida \& Jin, 2009, presence of a mesofossettid is gradually reduced relative to presence of a mesoflexid (morphotype PR1), in a sequence $100 \%-84 \%-33 \%$ (Fig. 6; Tomida \& Jin 2009). The only
European record of this genus is the Early Pliocene (MN15) P. dietrichi (Fejfar 1961), whose p3 exclusively has a morphotype PR1.

In the Pliocene (MN14-15) of Eastern Europe and the Middle East, the presence of a mesofossettid (morphotype PR2/A1) is common in the genus Trischizolagus (Fig. 6; Čermák \& Wagner 2013). In the European species T. dumitrescuae no significant changes in the proportion of PR1/A1 to PR2/A1 p3 patterns were observed during the Pliocene (Čermák \& Wagner 2013). Nevertheless, relatively large samples (of mixed ontogenetic age) from several localities of Eastern Europe show that on the occlusal surface of young individuals the mesofossettid is smaller (mesoflexid is shorter) than on the radical side. Thus, in occlusal view they look more archaic. The mesofossettid is almost exclusively placed lingually near the enamel border and its development is related to the mesoflexid. Pre-MN14 fossil findings assignable to Trischizolagus are very scarce and do not allow a reliable evaluation of morphotype composition.

A small mesofossettid is present very rarely in advanced European populations of Lower Pleistocene Hypolagus (PR0/A0 pattern), but this structure is derived from the medial end of the hypoflexid ( $c f$. Fladerer \& Reiner 1996) and has nothing to do with lingual structures. 
The mesofossettid observed in a p3 (AFG 759; SČ pers. obs.) from the Lower Pliocene ( $c f$. MN14) Pul-e Charkhi locality, Afghanistan (referred to Trischizolagus cf. maritsae in Șen 1983, Trischizolagus sp. in Averianov \& Tesakov 1997; Serengetilagus sp. in Șen \& Erbaeva 1995), likely has a similar origin.

In extant Old World species of Lepus (PR3/A1), the mesofossettid appears rarely ( $c a$ up to $1 \%$; Averianov \& Tesakov 1997). In European populations of Oryctolagus cuniculus (PR3/A1) an aberrant mesofossettid is also sometimes observed (Hibbard 1963).

The oldest leporid records in Africa are dated to the Late Miocene ( $c$ a 7.0-6.0 Ma). The p3 of these representatives, e.g., Serengetilagus tchadensis López Martínez et al., 2007 (Chad), and Alilepus sp. (near elongatus, Kenya), are predominantly limited to PR0/A0-A1 (Serengetilagus tchadensis) and PR1/A0/Pa0-Pa1 morphotypes (cf. López Martínez et al. 2007, Winkler \& Avery 2010, Winkler \& Tomida 2012). During the Pliocene, advanced species of Serengetilagus may extremely rarely have a mesofossettid: S. praecapensis Dietrich, 1941, from Tanzania (in 0.7\%, N = 143, Erbaeva \& Angermann 1983) and from Egypt (Fejfar \& Storch, unpubl. MS). The mesofossettid in these forms is large, antero-posteriorly elongated and almost square in shape. A well-developed mesofossettid is dominant in the leporid from the middle Pleistocene Grotte des Rhinocéros locality (Morocco), which, based on morphotype PR2/A1/Pa1 is referred generally to Trischizolagus (cf. e.g. Averianov \& Tesakov 1997, López Martínez et al. 2007).

\section{Notes on the evolution of the earliest Leporinae inferred from p3 phenotype: Old vs New World}

The fossil record of earliest Leporinae is almost exclusively limited to dental remains. Pros and cons of using teeth in taxonomy of Leporidae are discussed in Čermák \& Wagner (2013). The main evolutionary changes in the p3 of leporids are manifested predominantly in a selection in tooth patterns (/structural clusters) among the phylogenetic morphoclines leading to dominant $\mathrm{p} 3$ phenotypes. A continuous spectrum of morphologies between two particular features is less common and less obvious in leporids. During Late Miocene - Pliocene leporine evolution, the following main phylogenetic morphoclines were documented in $\mathrm{p} 3$ : (1) mesoflexid $=>$ (isolated to) enamel lake, (2) mesofossettid $=>$ (merged with) hypoflexid, (3) enamel lake $=>$ (open to) lingual side, (4) reduction of connection between trigonid and talonid => PR4 pattern, (5) enlargement of anteroflexid, and (6) enlargement of paraflexid (exceptionally evolved to "closed enamel structure" or even to $\mathrm{Pa} 2$ trigonid pattern; cf. e.g. White 1991, Voorhies \& Timperley 1997, Jin et al. 2010).
Voorhies \& Timperley (1997, p. 736) suggested that Hypolagus parviplicatus Dawson, 1958, or a closely related species, likely gave rise to the Leporinae clade. They considered the oldest member of the Leporinae to be Pronotolagus albus Voorhies \& Timperley, 1997. However, they also considered a coeval species, referred to Alilepus sp., to be close to H. fontinalis Dawson, 1958 (a more derived species than H. parviplicatus, and probably its direct descendant), and suggested their ancestor-descendant relationship. This taxonomic/phylogenetic model implies a diphyletic origin of Leporinae. At any rate, both $P$. albus and Alilepus sp. have significant complications of the lingual enamel pattern in $\mathrm{p} 3$ and it is very likely that the oldest leporine form comes from this stock, or a closely related form, by at least $c a 14 \mathrm{Ma}$. The relationships of descendant taxa proposed by White (1991) and Voorhies \& Timperley (1997) are more convincing and are supported here. The clade derived from $P$. albus comprises $P$. apachensis (Gazin, 1930) (Late Clarendonian-Early Hemphillian), and subsequently Notolagus and Paranotolagus (Hemphillian-Blancan). Alilepus hibbardi (derivable from Alilepus sp. from Stewart Quarry) most likely is the ancestor of Hemphillian - Blancan species of Alilepus, Nekrolagus, Pratilepus, etc. (see White 1991, Jin et al. 2010 for details). It is noteworthy that White (1991) assumed that Alilepus, Nekrolagus, Pratilepus and Aztlanolagus had similar development of postero-internal structures, following the sequence mesoflexid $\Rightarrow>$ mesofossettid $=>$ long hypoflexid (as proposed Hibbard 1963). In our view, this phenomenon is supported by the fossil record only in Nekrolagus and Pratilepus.

In contrast to the New World, proven Old World representatives of the earliest Leporinae appeared much later, during the Late Miocene (MN10-13; ca Late Clarendonian-Hemphillian). Forms with extensive enlargement of the paraflexid (morphological group Notolagus-Paranotolagus) never appeared in the Old World. The oldest Asian Leporinae are limited exclusively to Alilepus and evolved there in several phenotypic/evolutionary groups, each one corresponding to a presumed palaeobiogeographic path of dispersal:

1) First, a Far East group, is characterized by the reduction of the connection between trigonid and talonid, and the subsequent confluence of mesofossettid and hypoflexid (i.e., PR1/A0 $\Rightarrow>\mathrm{PR} 4 / \mathrm{A} 0$ ). The clade is represented by A. longisinuosus, which evolved into Nesolagus (Qiu \& Han 1986 followed by Jin et al. 2010).

2) Second, another Far East group, is characterised by development of the anteroflexid and the crenulation of $\mathrm{p} 3$. According to Jin et al. 2010, this clade was derived from A. lii and evolved into Pliopentalagus huainanensis (PR2/A1/Pa1). Pliopentalagus huainanensis probably gave rise to three branches with different development of the mesofossettid: (a) a lineage leading to other Pliopen- 
Table 2. Name-bearing types of European Alilepus species (*-designated in this paper).

\begin{tabular}{lllll}
\hline Species & Name-bearing type & Type specimen & Type locality \\
\hline Alilepus laskarewi (Khomenko, 1914) & lectotype * & right mandible (p3-m3) & Tarakliya (MD) \\
Alilepus hungaricus Kormos, 1934 & lectotype * & left mandible (p3-m2) & Polgárdi 2 (HU) \\
Alilepus ucrainicus Gureev, 1964 & holotype & right mandible (p3-p4, m2) & Odessa Catacombs (UA) & MN15b \\
Alilepus turolensis López Martínez, 1977 & holotype & isolated left p3 & El Arquillo (ES) & MN13 \\
Alilepus meini Angelone \& Rook, 2011 & holotype & isolated right p3 & Ribardella (IT) & MN13 \\
\hline
\end{tabular}

talagus species (PR2/A1/Pa1 => PR1/A1/Pa1); (b) a lineage leading to Poelagus and Caprolagus (PR2/A1/Pa1=> PR3/A1/Pa1); and (c) a lineage leading to Aztlanolagus (PR2/A1/Pa1 retained). In our view, based on the material presented here, it seems unlikely that $A$. lii can be the direct ancestor of $P$. huainanensis. Both species are almost coeval and the p3 pattern of $P$. huainanensis is limited exclusively to PR2/A1/Pa1. If the only specimen of $A$. lii does not represent an extreme morphotype, then one may expect in the ancestral taxon a significant presence of the mesofossettid. The new material of A. laskarewi presented here evidences a significant presence of the mesofossettid in the MN12 of Europe. Thus, similar forms may be expected in Asia at the same time, or even earlier. Moreover, as presented above, a tendency to tooth crenulation is also typical of these early forms. We expect in the ancestor of $P$. huainanensis (likely a pre-MN13 form) a significant presence of PR2/A1/Pa1 p3 morphotype together with a potential to tooth crenulation similar to that of A. laskarewi.

3) The third group, probably forming one separate clade, is represented by $\mathrm{S}$ Asiatic and NE African forms (i.e., A. elongatus from Pakistan and Alilepus sp. from Kenya) characterized by the elongation of the anteroconid with a potential to slight tooth crenulation.

4) At least one, probably north-Asiatic lineage, should lead to European Alilepus populations (cf. e.g., Jin et al. 2010, Flynn et al. 2014). Although A. annectens most likely belongs to this northern branch of Alilepus, taxonomical and palaeobiogeographical data presented here indicates that it cannot be linked directly with A. laskarewi. At any rate, a possible relationship of $A$. annectens with some other European Alilepus species cannot be excluded. Jin et al. (2010) suggested a close relationship of $A$. annectens with the ancestral type of Trischizolagus, but the new material presented here contradicts this hypothesis. The phenotypic compatibility of A. laskarewi with European populations of Trischizolagus, expressed particularly by the significant presence of $\mathrm{p} 3$ mesofossettid, may suggest their close relationship. The northern peri-Paratethyan distribution of both taxa also supports this hypothesis. In this perspective, it is not surprising that the development of the anteroflexid is a phenomenon that appeared independently several times in different lineages (White 1991). On the other hand, no intermediate forms with an incipient anteroflexid together with the PR2 p3 pattern suggesting this morphocline, have yet been recorded. From a palaeobiogeographic point of view it is noteworthy that the material from Palievo (UA) and Keinar (MD), presented above, suggest that $A$. laskarewi, or its close forms, was present in the peri-Paratethyan area at least from MN11.

\section{Conclusions}

We analyzed new material referred to Alilepus from eight Late Miocene localities of Ukraine and Moldova. The taxonomic consideration of this material was supported by a revision of type materials of all available (sensu ICZN 1999) European species of Alilepus, particularly by a direct analysis and re-description of yet very poorly known type materials of A. laskarewi, A. hungaricus and A. ucrainicus. Lectotypes of $A$. annectens (type species of the genus), A. laskarewi and A. hungaricus were designated here. The present state of name-bearing types of European Alilepus species is synoptically summarized in Table 2 .

The taxonomic analyses of the material under study resulted in individuation of $A$. laskarewi from MN12 locality Egorovka 2. The fragmentary and/or scarce materials from other studied localities are inadequate to confidently assign them to species or even to genus. Taking into account also their ages, the material from Andreevka (MN13) is tentatively assigned here as $A$. cf. hungaricus, the material from Cherevichnoe 3 (MN12) and Novoukrainka 1 (MN13) is tentatively assigned here as Alilepus sp., and the material from Keinar (MN11), Palievo (MN11), Kubanka 2 (MN12) and Tretya Krucha 2 (MN12) is tentatively assigned here as ?Alilepus sp.

Based on the new Alilepus material, particularly from Egorovka 2 and published relevant material from Chimishliya, Moldova (Delinschi 2014), we provided a re-description of $A$. lascarewi and formulated its emended diagnosis. These remains of $A$. laskarewi have a peculiar p3 phenotype, characterized by simple anteroconid and very high incidence of a mesofossettid (40\% of PR2/A0 vs $60 \%$ of PR1/A0). These characters discriminate this Late Miocene (known since at least the second half of MN12) leporid species from all Late Miocene and Pliocene Alilepus of the Old World, and changes our view of the phenotype distribution of earliest European Leporinae. 
It can be assumed, that a similar $\mathrm{p} 3$ phenotype (i.e., with significant presence of mesofossettid, potential to crenulation of anterior walls of talonids in lower molariforms, variable development of the anteroconid) was in existence in the later MN12 or earlier in Eastern Asia (Fig. 6). This pre-MN12 hypothetical form of Asia may represent the root phenotype (at least for some lineages), appearing in Asia as a result of one of the earliest immigration waves of leporines from North America via Beringia. This hypothetical form may also have given rise to clades derived from Alilepus longisinuosus and Pliopentalagus huainanensis (Fig. 6). At any rate, pre-MN12 (yet the oldest) records from Eastern Europe with probable affinities to Alilepus laskarewi are reported here from MN11 Palievo (UA) and Keinar (MD).

In the context of dispersal scenarios of leporids into Eurasia as proposed by Flynn et al. (2014), the relatively early presence of Alilepus in Eastern Europe can be explained as a result of limited dispersal prior to the successful main late Miocene influx. Considering the general features of A. laskarewi in the palaeobiogeographic and biochronologic context of the Asiatic and North American leporid fossil record, the roots of the lineage leading to A. laskarewi can be traced to near the Clarendonian/Hemphillian boundary, to the phyletic proximity of A. hibbardi stock.

In light of identified $\mathrm{p} 3$ morphology in studied Alilepus, we provided a synoptic survey of the mesofossettid (including similar structures) in all Eurasian and North American leporid taxa. Predisposition to development of this structure is present already in the earliest forms of Leporinae; the initial appearance is recorded from the Middle Miocene (Late Barstovian; $c a$ Late Astaracian, Late MN 6, $c a 13 \mathrm{Ma}$ ) of North America. The available fossil record suggests differing origins of this structure; based on its size, morphology and position in $\mathrm{p} 3$, it seems in many cases that it originated independently of a lingual isolation of the mesoflexid. Moreover, p3 morphotype changes over time within presumed lineages suggest also their different morphoclines (note east Asiatic lineage of Pliopentalagus, Tomida \& Jin 2009). The available data rather support limited validity of Hibbard's (1963) hypothesis proposing the development of postero-internal structures of $\mathrm{p} 3$ in the sequence mesoflexid $=>$ mesofossettid (although well documented in some North American leporines). In our view, this morphocline cannot be looked upon as a general phenomenon in all lineages of leporines.

\section{Acknowledgements}

We would like to express our thanks to Alexander O. Averianov (ZIN RAS), Emese Bodor (MFGI) and Adrian Delinschi (MENH) for access to collections in their care. A.O. Averianov also provided precious information about the type material of Alilepus ucrainicus. Last but not least, we express thanks to the referees Alisa J. Winkler (Southern Methodist University, Dallas), Lawrence J. Flynn (Harvard University, Cambridge) and Yukimitsu Tomida (National Museum of Nature and Science, Tokyo) for their critical reading and helpful comments on the manuscript. The study was supported by the RVO67985831 of the Institute of Geology, Academy of Sciences of the Czech Republic, v.v.i. and the Spanish Ministerio de Economía y Competitividad (CGL2011-28681).

\section{References}

Angelone, C. \& Rook, L. 2011. Alilepus meini n. sp., a new leporid (Leporidae, Lagomrpha) from the early Messinian of Tuscany (central western Italy). Geobios 44, 151-156. DOI 10.1016/j.geobios.2010.11.003

Averianov, A.O. 1996. The Neogene rabbit Hypolagus igromovi Gureev, 1964 (Lagomorpha, Leporidae) from southern European Russia. Acta zoologica cracoviensia 39(1), 61-66.

Averianov, A.O. \& Tesakov, A.S. 1997. Evolutionary trends in Mio-Pliocene Leporinae, based on Trischizolagus (Mammalia, Lagomorpha). Paläontologische Zeitschrift 71, 145-153. DOI 10.1007/BF03022556

Berggren, W.A., Kent, D.V., Swisher, C.C. \& Aubry, M.-P. 1995. A revised Cenozoic geochronology and chronostratigraphy, 129-212. In Berggren, W.A., Kent, D.V. \& HardenBol, J. (eds) Geochronology Time Scales and Global Stratigraphic Correlations: A Unified Temporal Framework for a Historical Geology. SEPM Special Publication No. 54. SEPM, Tulsa.

Boon-KristKoiz, E. \& KristKoIz, A.R. 1999. Order Lagomorpha, 259-262. In Rössner, G. \& HeIssig, K. (eds) The Miocene Land Mammals of Europe. Verlag Dr. Friedrich Pfeil, München.

BRANDT, J.F. 1855. Beiträge zur näheren Kenntniss der Säugethiere Russlands. Mémoire de l'Académie impériale des Sciences, St. Petersburg, Physique, Mathématique, et Naturalistique Séries 6(9), 1-365.

BRUIJN, H. DE 1995. The vertebrate locality Maramena (Macedonia, Greece) at the Turolian-Ruscinian boundary (Neogene). 11 - Lagomorpha (Mammalia). Münchner Geowissenschaftliche Abhandlungen A 28, 133-136.

ČERMÁK, S. 2009. The Plio-Pleistocene record of Hypolagus (Lagomorpha, Leporidae) from the Czech and Slovak Republics with comments on systematics and classification of the genus. Bulletin of Geosciences 84(3), 497-524. DOI 10.3140/bull.geosci.1104

ČERMÁK, S. \& Wagner, J. 2013. The Pliocene record of Trischizolagus and Pliopentalagus (Leporidae, Lagomorpha, Mammalia) in Central Europe with comments on taxonomy and evolutionary history of Leporinae. Neues Jahrbuch fur Geologie und Paläontologie Abhandlungen 268, 97-111. DOI 10.1127/0077-7749/2013/0321

Cheng, J., CaO, B., Tian, M. \& Li, L. 1995a. A new early Pleistocene Mammalian fauna from Zhoukoudian. Earth Science (Wuhan) 20, 497-504. 
Cheng, J., CaO, B., Tian, M., Yuan, L., Zhao, Z., Li, L., Li, C. \& Chen, L. 1995b. Early Pleistocene cave deposits with fossil mammals at Zhoukoudian. Geoscience 9, 441-449.

Dawson, M. 1958. Late Tertiary Leporidae of North America. University of Kansas Paleontological Contributions 6, 1-75.

DAXner, G. \& FeJfar, O. 1967. Über die Gattung Alilepus Dice, 1931 und Pliopentalagus Gureev, 1964 (Lagomorpha, Mammalia). Annalen des Naturhistorischen Museums Wien 71, $37-55$.

Delinschi, A. 2014. Late Miocene lagomorphs from the Republic of Moldova. Annales de Paléontologie 100, 157-163. DOI 10.1016/j.annpal.2013.10.004

Deng, T. 2006. Chinese Neogene mammal biochronology. Vertebrata Palasiatica 44, 143-163.

DieTRICH, W.O. 1941. Die säugetierepaläontologischen Erhebnisse der Kohl-Larsen'schen Expedition 1937-1939 in nördlichen Deutsch-Ostafrika. Zeitblatt Mineralogie $B \quad 8$, 217-223.

Dice, L.R. 1917. Systematic position of several tertiary lagomorphs. University of California Publications, Bulletin of the Department of Geology 10, 179-183.

Dice, L.R. 1929. The phylogeny of the Leporidae, with description of a new genus. Journal of Mammalogy 10, 340-344. DOI $10.2307 / 1374124$

Dice, L.R. 1931. Alilepus, a new name to replace Allolagus Dice, preoccupied, and notes on several species of fossil hares. Journal of Mammalogy 12, 159-160. DOI 10.2307/1373916

Downey, J.S. 1968. Late Pliocene Lagomorphs of the San Pedro Valley, Arizona. United States Geological Survey, Professional Paper 600D, 169-173.

Erbaeva, M.A. \& Angermann, R. 1983. Das Originalmaterial von Serengetilagus praecapensis Dietrich, 1941 - ergänzende Beschreibung und vergleichende Diskussion. Schriftenreihe für geologische Wissenschaften 19/20, 39-60.

Fahlbusch, V., Qiu, Z.-D. \& Storch, G. 1983. The Neogene mammalian faunas of Ertemte and Harr Obo in Nei Mongol, China. - I. Report on field work in 1980 and preliminary results. Scientia Sinica B 26, 205-224.

FeJFAR, O. 1961. Die plio-pleistozänen Wirbeltierfaunen von Hajnáčka und Ivanovce (Slowakei), ČSSR. III. Lagomorpha. Neues Jahrbuch für Geologie und Paläontologie, Monatshefte 1961(5), 267-282.

FeJfar, O. \& HeInRICH, W.-D. 1983. Arvicoliden-Sukzession und Biostratigraphie des Oberpliozäns und Quartärs in Europa. Schriftenreihe für Geologische Wissenschaften 19/20, 61-109.

FeJFAR, O., HeinRICH, W.-D. \& LindSAy, E.H. 1998. Updating the Neogene Rodent biochronology in Europe. Mededelingen Nederlands Instituut voor Toegepaste Geowetenschappen TNO 60, 533-554.

Fejfar, O., Heinrich, W.-D., Kordos, L. \& Maul, L.C. 2011. Microtoid cricetids and the early history of arvicolids (Mammalia, Rodentia). Palaeontologia Electronica 14(3), 27A: 1-38; palaeo-electronica.org/2011_3/6_fejfar/index.html

Fischer, J.G. 1817. Adversaria zoologica. Mémoires de la Société Impérialle Naturelle (Moscow) 5, 368-428.

FlaDERER, F.A. 1987. Beitrag zur Entwicklung von Hypolagus und Lepus (Lagomorpha, Mammalia) im Pliopleistozän von Mitteleuropa. Sitzungsberichte der Österreichische Akademie der Wissenschaften, Mathematisch-naturwissenschaftliche Klasse, Abteilung I 196, 123-138.

Fladerer, F.A. \& ReInER, G. 1996. Evolutionary shifts in the first premolar pattern of Hypolagus beremendensis (Petényi, 1964) (Lagomorpha, Mammalia) in the Plio-Pleistocene of Central Europe. Acta zoologica cracoviensia 39, 147-160.

Flynn, L.J., Winkler, A.J., Erbaeva, M., Alexeeva, N., Anders, U., Angelone, C., Čermák, S., Fladerer, F.A., KraAtz, B., Ruedas, L.A., Ruf, I., Tomida, Y., Veitschegger, V. \& Zhang, Z. 2014. The Leporid Datum: A late Miocene biotic marker. Mammal Review 44(3-4), 164-176.

DOI 10.1111/mam.12016

FlynN, L.J., Wu, W.Y. \& Downs, W.R. 1997. Dating vertebrate microfaunas in the late Neogene record of Northern China. Palaeogeography, Palaeoclimatology, Palaeoecology 133, 227-242. DOI 10.1016/S0031-0182(97)00082-5

Gazin, C.L. 1930. A Tertiary vertebrate fauna from the upper Cuyama drainage basin, California. Carnegie Institution of Washington 404, 55-76.

GazIN, C.L. 1934. Fossil Hares from the Late Pliocene of Southern Idaho. Proceedings of the United States National Museum 83(2976), 111-121. DOI 10.5479/si.00963801.83-2976.111

GuReEv, A.A. 1964. Fauna of the USSR (Lagomorpha), Vol. 3 (10). 276 pp. Nauka, Moscow \& Leningrad. [in Russian]

HibBARD, C.W. 1939a. Four new rabbits from the upper Pliocene of Kansas. American Midland Naturalist 21(2), 506-513. DOI 10.2307/2420552

HibBard, C.W. 1939b. Nekrolagus, new name for Pediolagus Hibbard, not Marelli. American Midland Naturalist 21(3), Table of Contents.

HibBaRd, C.W. 1963. The origin of the p3 pattern of Sylvilagus, Caprolagus, Oryctolagus and Lepus. Journal of Mammalogy 44, 1-15. DOI 10.2307/1377162

HibBard, C.W. 1969. The rabbits (Hypolagus and Pratilepus) from the Upper Pliocene, Hagerman Local Fauna of Idaho. Papers of the Michigan Academy of Science, Arts, and Letters 1(1), 81-97.

Hulva, P., Horáček, I. \& Benda, P. 2007. Molecules, morphometrics and new fossils provide an integrated view of the evolutionary history of Rhinopomatidae (Mammalia: Chiroptera). BMC Evolutionary Biology 7, 165, 1-28.

ICZN 1999. International Code of Zoological Nomenclature, $4^{\text {th }}$ Edition. XXIX $+306 \mathrm{pp}$. International Trust for Zoological Nomenclature, London.

JiN, C.Z. 2004. Fossil leporids (Mammalia, Lagomorpha) from Huainan, Anhui, China. Vertebrata PalAsiatica 42, 230-245. [in Chinese, English summary]

Jin, C.Z., TomidA, Y., WANG, Y. \& ZhanG, Y. 2010. First discovery of fossil Nesolagus (Leporidae, Lagomorpha) from Southeast Asia. Science China Earth Sciences 53, 1134-1140. DOI 10.1007/s11430-010-4010-3

Khomenko, J. 1914. La faune méotique du village Taraklia du district de Bendery. Travaux de la Société des Naturalistes et des Amateurs des Sciences Naturelles de Bessarabie 5, 1-55.

Kormos, T. 1911. Der pliozäne Knochenfund bei Polgárdi (Vorläufiger Bericht). Földtani Közlöny 41, 171-189.

KoRmos, T. 1934. Az euráziai nyulak származástani problémája Zur Frage der Abstammung eurasiatischer Hasen. Allatani Közlemények 31, 65-78. 
KorotKevich, E.L. 1988. A history of foundation of hipparion fauna of Eastern Europe. 164 pp. Naukova dumka, Kiev. [in Russian]

KretzoI, M. 1954. Befejezô jelentés a Csakvári barlang őslénytani feltásáról [Final report on the paleontological findings in the cave of Csákvár]. A Magyar Állami Földtani Intézet Évi Jelentése az 1952 Évról 1952, 37-69. [in Hungarian]

López Martínez, N. 1976. Lagomorpha from the Turolian of Pikermi (Greece). Proceedings Koninklijke Nederlandse Akademie van Wetenschappen 79, 235-244.

López MartíneZ, N. 1977. Nuevos Lagomorfos (Mammalia) del Neógeno y Cuaternario español. Trabajos sobre NeógenoCuaternario 8, 7-45.

LóPEZ MARTíNEZ, N. 1989. Revisión sistemática y biostratigráfica de los Lagomorpha (Mammalia) del Terciario y Cuaternario de España. Memorias del Museo Paleontológico de la Universidad de Zaragoza 3, 1-342.

LóPEZ MARTínEZ, N. 2008. The lagomorph fossil record and the origin of the European rabbit, 27-46. In Alves, P.C., FERRAND, N. \& HACKLÄNDER, K. (eds) Lagomorph Biology: Evolution, Ecology and Conservation. Springer-Verlag, Berlin \& Heidelberg.

López Martínez, N., Likius, A., Mackaye, H.T., Vignaud, P. \& BRunEt, M. 2007. A new Lagomorph from the Late Miocene of Chad (Central Africa). Revista Española de Paleontología 22, 1-20.

Lungu, A. 1980. New records of the Sarmatian land vertebrate fauna in Moldavia, 3-8. In Quaternary and neogene faunas and floras of Moldavian SSR. Shtiintsa, Kishinev. [in Russian]

Lungu, A. \& RzeBiK-Kowalska, B. 2011. Faunal assemblages, stratigraphy and taphonomy of the Late Miocene localities in the Republic of Moldova. $62 \mathrm{pp}$. Institute of Systematics and Evolution of Animals Polish Academy of Sciences, Krakow.

Lungu, A., Delinschi, A. \& Nicoara, I. 2007. Some dates about studies representative order Lagomorpha from hipparion fauna, of superior Miocen from Republic of Moldova. Scientific Bulletin of National Museum of Ethnography and Natural History of Moldova. Ethnography, Natural Sciences and Museology 6(19), 141-143.

MeIN, P. 1988. Continental faunas at the Miocene-Pliocene boundary. La gisement karstique turolien de Lissieu (Rhône). International Workshop "Continental Faunas at the Miocene/Pliocene Boundary”. Proceedings, Faenza, 25.

MeIN, P. 1999. The late Miocene small mammal succession from France, with emphasis on the Rhône Valley localities, 140-164. In Agustí, J., Rook, L. \& Andrews, P. (eds) The Evolution of Terrestrial Ecosystems in Europe, Volume 1. Hominoid Evolution and Climatic Change in Europe. Cambridge University Press, Cambridge.

Miller, W.E. \& Carranza-Castaneda, O. 1982. New lagomorphs from the Pliocene of central Mexico. Journal of Vertebrate Paleontology 2, 95-107.

DOI 10.1080/02724634.1982.10011920

Nesin, V.A. 1996. Lower Pliocene rodents of Ukraine and problems of Pontian biostratigraphy. Acta zoologica cracoviensia 39(1), 395-399.

Nesin, V.A. 2004. Stratigraphical position of the Late Neogene localities of the microtheriofauna in Ukraine, 195-199. In GozHI, P.F. (ed.) Problemy stratigrafii i fanerozoyu Ukrainy. Institut geologichnikh nauk, Kiev. [in Russian]
Nesin, V.A. 2013. The Neogene Murinae (Rodentia, Muridae) of Ukraine. 174 pp. University book, Sumy. [in Russian, English summary]

Nesin, V.A. \& Nadachowski, A. 2001. Late Miocene and Pliocene small mammal faunas (Insectivora, Lagomorpha, Rodentia) of Southeastern Europe. Acta zoologica cracoviensia 44(2), 107-135.

Ognev, S.I. 1929. Zur Systematic der russischen Hasen. Zoologischer Anzeiger 84, 68-83.

Palacios, F. \& López Martínez, N. 1980. Morfología dentaria de las liebres europeas (Lagomorpha, Leporinae). Doñana Acta Vertebrata 7, 61-81.

Qi, G.-Q., Dong, W., Zheng, L., Zhao, L., GaO, F., Yue, L.-P. \& ZHANG, Y.-X. 2006. Taxonomy, age and environment status of the Yuanmou hominoids. Chinese Science Bulletin 51, 704-712. DOI 10.1007/s11434-006-0704-5

Qiv, Z.-D. 1987. The Neogene mammalian faunas of Ertemte and Harr Obo in Inner Mongolia (Nei Mongol), China. 6. Hares and pikas - Lagomorpha: Leporidae and Ochotonidae. Senckenbergiana lethaea 67, 375-399.

Qiv, Z. \& HAN, D. 1986. Fossil Lagormorpha from the hominoid locality of Lufeng, Yunnan. Acta Anthropologica Sinica 5, 41-53. [in Chinese, English summary]

Qıu, Z. \& QIU, Z. 1995. Chronological sequence and subdivision of Chinese Neogene mammalian faunas. Palaeogeography, Palaeoclimatology, Palaeoecology 116, 41-70.

DOI 10.1016/0031-0182(94)00095-P

Qiu, Z., Wu, W. \& Qiu, Z. 1999. Miocene mammal faunal sequence of China: paleozoogeography and Eurasian relationships, 443-445. In Rössner, G.E. \& HeIssig, K. (eds) The Miocene Land Mammals of Europe. Verlag Dr. Friedrich Pfeil, München.

Rabeder, G. 1989. Die Säugetiere des Pontien in Österreich und Ungarn. Jugoslawische Akademie der Wissenschaften und Künste 8, 821-836.

RADDE, G. 1861. Neue Säugethier-Arten aus Ost-Sibirien. Mélanges Biologiques tirés du Bulletin Physico-Mathematique de l'Académie Impériale des Sciences de St. Petersbourg 3, 676-687.

Radulesco, C. \& SAmson, P. 1967. Contribution à la connaissance du complexe faunistique de Malusteni-Beresti (Pléistocène inférieur), Roumanie I. Ord. Lagomorpha, Fam. Leporidae. Neues Jahrbuch für Geologie und Paläontologie, Monatshefte 1967(9), 544-563.

Russels, B.D. \& HARRIS, A.H. 1986. A new leporine (Lagomorpha: Leporidae) from Wisconsinan deposits of the Chihuahuan Desert. Journal of Mammalogy 67, 632-639. DOI $10.2307 / 1381125$

Schlosser, M. 1924. Tertiary vertebrates from Mongolia. Palaeontologia Sinica, Series C 1(1), 1-133.

ȘEN, Ș. 1983. Rongeurs et lagomorphes du gisement Pliocène de Pul-e Charkhi, basin de Kabul, Afghanistan. Bulletin du Museum National d'Histoire Naturelle, Paris, 5e séries, 5C(1), 33-74.

Șen, Ș. \& Erbaeva, M. 1995. Early Pliocene leporids (Mammalia, Lagomorpha) from Afghanistan. Comptes Rendus de l'Académie des Sciences de Paris, Sér. II 320, 1225-1231.

Semenenko, V.N. 1987. [Stratigraphical Correlation of the Upper Miocene and Pliocene of the Eastern Paratethys and Tethys]. 230 pp. Naukova dumka, Kiev. [in Russian] 
Sinitsa, M.V. 2005. The small mammal fauna (Insectivora, Lagomorpha, Rodentia) from the Meotian deposits of Kuyalnik River. Proceedings of the museum Brauner's foundation 11(4), 11-17. [in Russian]

SinitsA, M.V. 2008. Meotian small mammals from the Egorovka locality, 285-289. In GozHIK, P.F. (ed.) Biostratigraphic fundamentals of creating the stratigraphic schemes of the Phanerozoic of Ukraine. Proceedings of the Institute of Geological Sciences of the NAS of Ukraine, Kyiv. [in Russian, English summary]

Sinitsa, M.V. 2009a. Cricetids (Rodentia, Mammalia) from the Upper Miocene of Egorovka locality. Vestnik zoologii 44, 209-225. [in Russian, English summary]

SinITSA, M.V. 2009b. A new small mammal fauna from the Lower Turolian (MN11) of the Southern Ukraine, 181-182. In Codreanu, I. (ed.) Materialele simpozionului jubiliar internațional 'Mediul și dezvoltarea durabilă'. Labirint, Chișinău.

Sinitsa, M.V. 2011. Pliopetaurista (Mammalia, Rodentia) from the Neogene of Ukraine. Vestnik zoologii 45, 19-33. [in Russian, English summary]

Sinitsa, M.V. 2012. Cricetids (Mammalia, Rodentia) from the Late Miocene locality Palievo, Southern Ukraine. Vestnik zoologii 46, 137-147. [in Russian, English summary]

Steininger, F.F. 1999. The Continental European Miocene. Chronostratigraphy, Geochronology and Biostratigraphy of the Miocene "European Land Mammal Mega-Zones" (ELMMZ) and the Miocene "Mammal-Zones (MN-Zones)", 9-24. In RössNER, G.E. \& HeIssig, K. (eds) The Miocene Land Mammals of Europe. Verlag Dr. Friedrich Pfeil, München.

Sych, L. 1965. Fossil Leporidae from the Pliocene and the Pleistocene of Poland. Acta zoologica cracoviensia 10, 1-88.

TomidA, Y. 2008. Can morphological differences among extinct species be explained by means of genetics? An example from fossil rabbits. Journal of Vertebrate Paleontology 28 (3, Supplement), 152A.

TomidA, Y. \& Jin, C.-Z. 2009. Two new species of Pliopenta- lagus (Leporidae, Lagomorpha) from the Pliocene of Anhui Province, China, with a revision of $P l$. huainanensis. Vertebrata PalAsiatica 47(1), 53-71.

TopacheVski, V.A. \& Skorik, A.F. 1992. The Neogene and Pleistocene lower cricetids of SE Europe. 242 pp. Naukova dumka, Kiev. [in Russian, English summary]

Topachevski, V.A., Nesin, V.A. \& Topachevski, I.V. 2000. A small mammal oryctocenoses in the Meotian of the Cherevichnoe section. Proceedings of the National Academy of Sciences of Ukraine 10, 192-195. [in Russian, English summary]

Voorhies, M.R. \& Timperley, C.L. 1997. A new Pronotolagus (Lagomorpha: Leporidae) and other leporids from the Valentine Railway Quarries (Barstovian, Nebraska), and the archaeolagine-leporine transition. Journal of Vertebrate Paleontology 17, 725-737.

DOI 10.1080/02724634.1997.10011020

White, J.A. 1991. North American Leporinae (Mammalia: Lagomorpha) from late Miocene (Clarendonian) to latest Pliocene (Blancan). Journal of Vertebrate Paleontology 11, 67-89. DOI 10.1080/02724634.1991.10011376

White, J.A. \& Morgan, N.H. 1995. The Leporidae (Mammalia: Lagomorpha) from the Blancan (Pliocene) Taunton Local Fauna of Washington. Journal of Vertebrate Paleontology 15, 366-374. DOI 10.1080/02724634.1995.10011235

WiLson, R.W. 1938. A new genus of lagomorph from the Pliocene of Mexico. Bulletin of the Southern California Academy of Sciences 36(3), 98-104.

Winkler, A.J. \& Avery, M. 2010. Lagomorpha, 305-317. In Werdelin, L. \& SAnders, W.J. (eds) Cenozoic Mammals of Africa. University of California Press, Berkeley.

WinkleR, A.J. \& TomidA, Y. 2012. The fossil record of African leporids. $4^{\text {th }}$ World Lagomorph Conference, Proceedings, Vienna, 139.

Winkler, A.J., Flynn, L.J. \& Tomida, Y. 2011. Fossil lagomorphs from the Potwar Plateau, northern Pakistan. Palaeontologia Electronica 14(3), 38A, 1-16; palaeo-electronica.org/2011_3/17_winkler/index.html 